OPEN ACCESS

Edited by:

Anthony Knap,

Texas A\&M University Central Texas,

United States

Reviewed by:

Xiubao Li,

Hainan University, China Xiaoshou Liu,

Ocean University of China, China

*Correspondence: Jorge Cortés

jorge.cortes@ucr.ac.cr John C. Ogden jogden@usf.edu

Specialty section: This article was submitted to Marine Evolutionary Biology, Biogeography and Species Diversity,

a section of the journal

Frontiers in Marine Science

Received: 24 September 2018 Accepted: 21 December 2018

Published: 14 January 2019

Citation:

Cortés J, Oxenford HA, van Tussenbroek $B l$, Jordán-Dahlgren E, Cróquer A Bastidas C and Ogden JC (2019) The CARICOMP Network of Caribbean Marine Laboratories (1985-2007):

History, Key Findings, and Lessons Learned. Front. Mar. Sci. 5:519. doi: 10.3389/fmars.2018.00519

\section{The CARICOMP Network of} Caribbean Marine Laboratories (1985-2007): History, Key Findings, and Lessons Learned

\author{
Jorge Cortés ${ }^{1 *}$, Hazel A. Oxenford ${ }^{2}$, Brigitta I. van Tussenbroek ${ }^{3}$, Eric Jordán-Dahlgren ${ }^{3}$, \\ Aldo Cróquer ${ }^{4}$, Carolina Bastidas ${ }^{5}$ and John C. Ogden ${ }^{6 *}$ \\ ${ }^{1}$ Centro de Investigación en Ciencias del Mar y Limnología, Universidad de Costa Rica, San José, Costa Rica, ${ }^{2}$ Centre \\ for Resource Management and Environmental Studies, University of the West Indies, Cave Hill, Barbados, ${ }^{3}$ Unidad \\ Académica Sistemas Arrecifales/Puerto Morelos, Instituto de Ciencias del Mar y Limnologia, Universidad Nacional \\ Autónoma de México, Puerto Morelos, Mexico, ${ }^{4}$ Laboratory of Experimental Ecology, Department of Environmental Studies, \\ Universidad Simón Bolivar, Caracas, Venezuela, ${ }^{5}$ Sea Grant College Program, Massachusetts Institute of Technology, \\ Cambridge, MA, United States, ${ }^{6}$ Department of Integrative Biology, University of South Florida, Tampa, FL, United States
}

Caribbean Coastal Marine Productivity (CARICOMP) was a basin-wide cooperative, international network of marine laboratories established in 1985. Recognizing major trends of change in coastal ecosystems and the importance of the linkages among them, our goal was to monitor synoptically with standardized methods the physical environment and to document trends in measures of the structure and functioning of coral reefs, seagrasses and mangroves. Between 1985 and 1993, the CARICOMP Steering Committee established a data management center and wrote a methods manual. Marine laboratories joined the program by appointing a Site Director and signing an agreement specifying the cost sharing and responsibilities of the laboratory. With significant outside funding in 1992, the program became fully functional and ultimately more than 30 institutions in 21 Caribbean countries participated. Monitoring lasted from 1992 to 2007, spanning many technological advances including the internet, automated in situ data logging and remote sensing. Annual CARICOMP meetings, organized at a different laboratory each year, were essential in standardization of methods and maintaining interest. Open access to the data was a goal from the start, although the members imposed an embargo to allow time to publish major results. At some of the sites, monitoring continues to this day, generating among the longest coastal monitoring data sets in the Caribbean, and possibly in the world. Over time, multi-authored papers were prepared for the Proceedings of the International Coral Reef Symposia and other journals, and independent scientists drew on the open database for regional analyses of ecosystem trends. Recently, active members have written summary papers based on the monitoring data covering physical parameters, coral reefs, seagrasses, and mangroves. Overall, the data reveal major differences across the region and changing rates and trends showing the dynamism and vulnerability of coastal ecosystems. The 
longer the monitoring continues, the more valuable the dataset becomes as a tool to discern the underlying factors driving the structure and functioning of Caribbean coastal ecosystems. Several recent workshops have concluded that the need for regionally cooperative monitoring and research has never been greater.

Keywords: CARICOMP network, standardized monitoring, Caribbean, coral reefs, seagrasses, mangroves, lessons learned

\section{A BRIEF HISTORY}

Caribbean Coastal Marine Productivity (CARICOMP) was a regional cooperative scientific network of Caribbean marine laboratories, best known for its long-term monitoring program of coral reefs, seagrasses and mangroves (CARICOMP, 1997a) (Figure 1). The network was established in 1985 as a response to the widespread observations of disturbing trends in the health of Caribbean coastal communities that emerged during the annual scientific meetings of the Association of Marine Laboratories of the Caribbean (AMLC) (Ogden, 1987). Despite the knowledge at that time that these coastal marine ecosystems are generally linked and inter-dependent, most scientists were monitoring the structure and function of only one ecosystem, and there was no coordination, standardization of methods or synchronization of sampling among sites or studies. This made quantitative comparison between widely separated field sites and ecosystems difficult or impossible.

A brief timeline of the CARICOMP program is illustrated in Figure 2. In the early 1980s, Marc Steyaert, director of the UNESCO Coastal Marine (COMAR) program visited the West Indies Laboratory of Fairleigh Dickinson University in St. Croix, United States Virgin Islands and offered to sponsor an international workshop to examine the inter-connections between Caribbean coastal ecosystems with attention to their conservation and management. In May 1982, 32 scientists from about 20 marine laboratories considered inter-connections by nutrients, dissolved and particulate organic material, daily movements of organisms, the importance of seagrass and mangrove nurseries and spawning sites and the impact of human disturbance on each system. Part of the workshop report (Ogden and Gladfelter, 1983) concerned an inventory of coastal ecosystems in several Caribbean counties and territories and the general availability of research and training facilities. The workshop recommended that UNESCO through COMAR and the Intergovernmental Oceanographic Commission (IOC) sponsor cooperative research based at marine laboratories across the region using standardized equipment and protocols to monitor the structure and functioning of the ecosystems of the coastal zone and strengthen regional scientific and management capabilities.

In November 1985 with the continued support of UNESCO COMAR, 43 scientists representing over 30 Caribbean marine laboratories attended a planning workshop at Discovery Bay Marine Laboratory of the University of the West Indies in Jamaica. The discussions focused on the factors influencing ecosystem structure and biological productivity in the coastal zone and the design of a long-term multinational comparative research program to be conducted by marine laboratories within the CARICOMP network. The emphasis was on scientific research with standardized methods and sampling, training and technology exchange, and offering assistance in the development of regional coastal management strategies. The participants selected a Steering Committee (SC) of eight scientists and two ex-officio members representing institutions encompassing the Caribbean (Ogden and Gladfelter, 1986).

In 1983-1984, the first widespread coral bleaching event occurred in the Caribbean. A link to seasonally high seawater temperatures had already been established but it was quickly noted that there were few long-term records of Caribbean seawater temperatures. One of the longest was a daily bucket temperature taken by the boatman ferrying people to the University of Puerto Rico Marine Laboratory on Isla Magueyes. A United States Congressional hearing emphasized the need for Caribbean seawater temperature data and participants at the Fifth International Coral Reef Symposium in Tahiti in 1985 started the Global Coral Reef Monitoring Network, urging that all research institutions near coral reefs establish, at the very least, water temperature monitoring programs.

Encouraged by these events, the SC met with UNESCO to solicit support at different marine labs and worked on a CARICOMP administrative structure and research design, outlined a standardized methods manual, and planned for data management. At the time, the internet was unavailable in most locations and communication was by telephone or regular mail. One of the first projects of the SC was a bibliography of relevant papers on the three coastal ecosystems distributed by mail.

In 1988, the CARICOMP administrative center moved to the Florida Institute of Oceanography (FIO) of the University of South Florida (USF) in St. Petersburg. The SC made several unsuccessful trips to Washington, DC to solicit funding from international agencies and regional development banks. These agencies, experienced in bi-lateral projects, viewed the multilateral structure of CARICOMP as too complex to manage. Finally, the new John D. and Catherine T. MacArthur Foundation responded to a SC solicitation and provided a substantial grant for CARICOMP Phase I (1991-1994). Adapting to the interests of our new sponsor, we expanded the membership of the network to Caribbean marine parks and reserves (CARICOMP, 1997a; Woodley, 1998; Alcolado et al., 2001).

As the internet became more widespread, communications and exchange improved greatly and in 1990, 1992, and 1993 workshops drafted and tested the CARICOMP Level I Methods Manual (CARICOMP, 2001) designed to allow all member institutions to participate in simultaneous, standardized sampling of all three critical coastal ecosystems: coral reefs, 


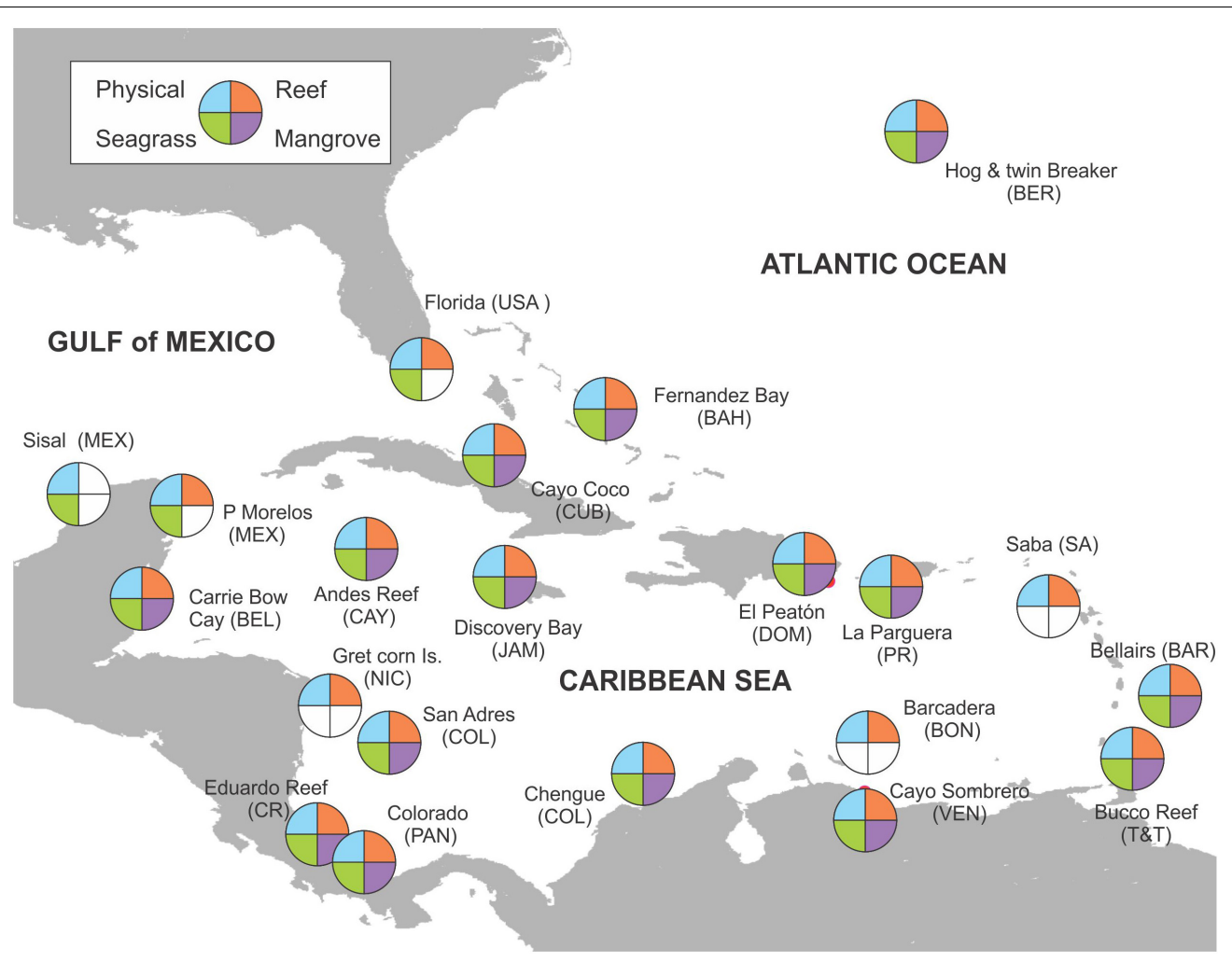

FIGURE 1 | Caribbean map showing the main CARICOMP sampling sites where mid- to long-term series where obtained. At several countries more than one replicate site was established whereas at others few data were obtained and are not shown due to the map scale. Empty (white) sections in plots indicate no data collected at that site.

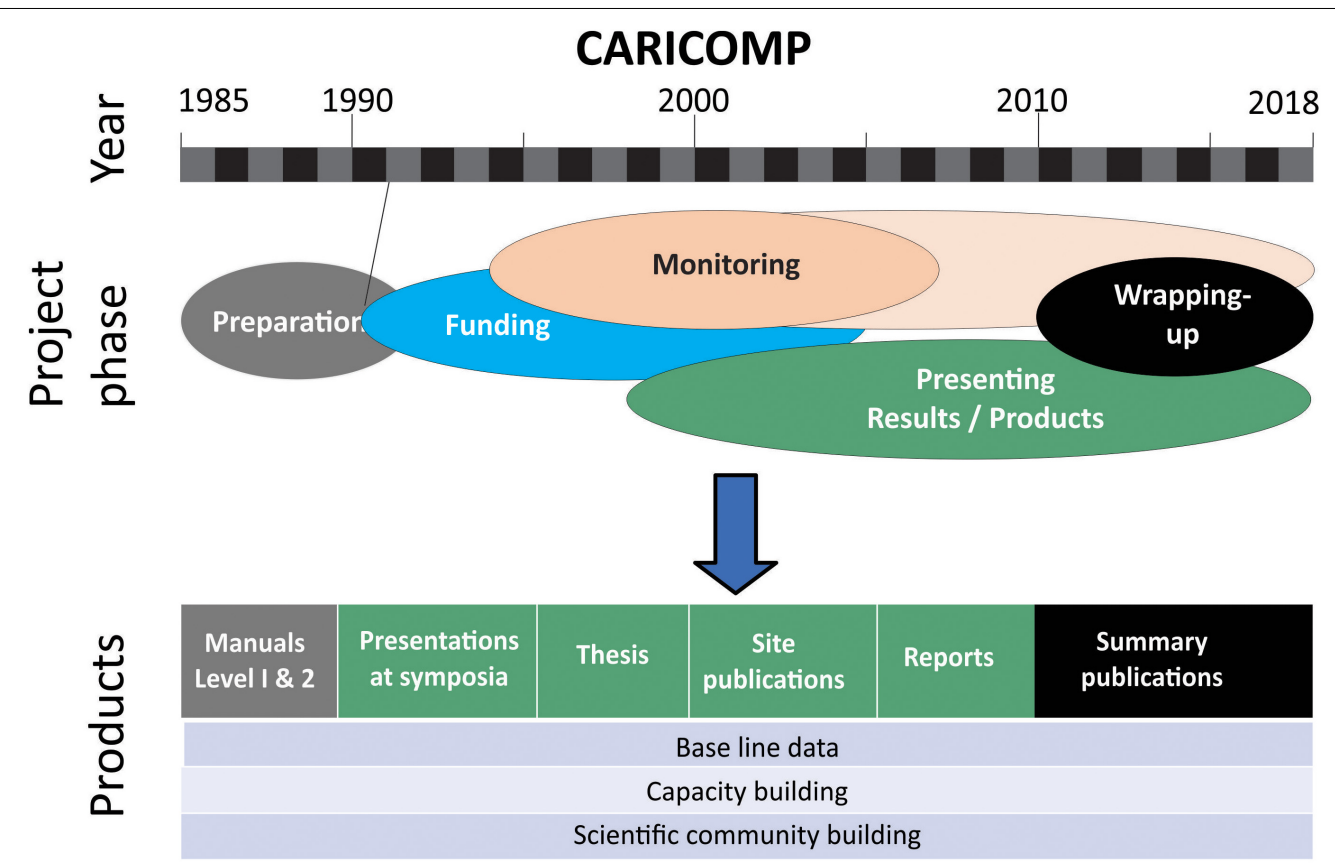

FIGURE 2 | A summary of the timeline of the CARICOMP program showing the phases of implementation and significant outputs. Monitoring officially finished between 2005 and 2007; but some sites continue up to the present. 
mangroves and seagrasses. At the same time, more sophisticated methods requiring specialized laboratory analyses were designated Level II for use by participants with appropriate capacity. The FIO assembled and sent, by freight, wooden boxes containing the Level I equipment to all participating institutions.

\section{MATERIALS AND METHODS}

\section{Network Membership}

Participation in the CARICOMP network was open and voluntary, requiring only a signed cost-sharing agreement in the form of a Memorandum of Understanding by the laboratory director specifying the selection of a Site Director and pledging implementation of the data collection protocols and timely reporting of data. For its part, the SC specified support with monitoring equipment and travel for the Site Director to attend annual meetings held at a participating institution. As such, CARICOMP was a collaborative network of institutions rather than individuals. This is an important distinction, as participating institutions contributed in-kind support such as salaries, facilities and boats matching grant funds.

\section{Data Collection Protocols}

The broad objectives of the CARICOMP monitoring program were to document spatial differences and temporal (seasonal and long-term) changes in structure and function of coastal ecosystems (coral reefs, seagrasses and mangroves) across the Caribbean region. Since the original idea was to obtain information on 'natural' patterns, sites were selected, wherever possible, in undisturbed sites away from direct anthropogenic impacts.

Simple standardized data collection protocols were fundamental to the CARICOMP monitoring program to maximize the likelihood of successful long-term monitoring across the region by member institutions with vastly different levels of capacity. These are explained in detail in the CARICOMP Level I Methods Manual (CARICOMP, 2001) and the Site Directors of member institutions received practical field training at the outset, in a workshop held at the Discovery Bay Marine Laboratory, University of the West Indies, Jamaica. Furthermore, data collection challenges were discussed, advice was given and additional training was offered at the annual meetings to ensure continuity of the standardized protocols. Here, we provide only a very brief overview of the key elements of the Level I protocols that were adopted in each of the three coastal ecosystems.

For coral reefs, CARICOMP adopted the full contact chain transect method along 10 permanently marked transects, a variation of the line transect intercept method (Loya, 1978), to assess coral diversity and reef community structure at approximately $10 \mathrm{~m}$ depth. The chain method offered two major advantages for describing reef communities given the aims of the network: (1) it was quick and easy to use, and (2) it provided data on both benthic community structure and rugosity. The first point was extremely important, as we needed a rapid and low-cost method accessible to everyone interested in joining and collecting data. The second advantage was also important as rugosity is an important attribute of a healthy reef and reef flattening (the loss of three-dimensional structural complexity) is among the major problems on Caribbean coral reefs (Alvarez-Filip et al., 2009). The analysis presented in this paper only encompassed live coral cover and macroalgae because these variables are considered good proxies of coral health. The description of spatial and temporal trends of the coral community (i.e., coral species composition and abundance) will be presented elsewhere (Cróquer et al., unpublished).

For seagrasses, a minimum of two permanent sampling stations were established at each site to measure seagrass species composition, total plant biomass and productivity using both subsurface cores and surface quadrats. Leaf area index was also obtained for Thalassia testudinum. Replicate cores were used to assess seagrass species composition and total plant biomass (above and below ground fractions) by species. Replicate quadrats $(10 \times 20 \mathrm{~cm})$ were used to measure T. testudinum leaf growth rate, by marking the short shoots and measuring the position of the mark after several days.

For mangroves, forest structure was assessed in replicate plots of $10 \times 10 \mathrm{~m}$ established in fringing red mangroves wherever possible and permanently marked for the course of the study. In each plot, mangrove trees were marked, their $\mathrm{XY}$ location within the plot recorded and various standard forestry measurements taken including: trunk circumference above the first prop-root (proxy for diameter at breast height); height from ground to first prop-root; height to first branch; height of canopy. Several $1 \times 1 \mathrm{~m}$ sub-plots were also established to monitor saplings and seedlings (number and height). To assess productivity, up to 10 litter-fall traps of $0.25 \mathrm{~m}^{2}$ were placed within each plot. Traps had a mesh of $1.5 \mathrm{~mm}$ and were tied to red mangroves prop-roots above high tide mark. Floor litter was also collected simultaneously from 10 quadrats $\left(0.25 \mathrm{~m}^{2}\right)$. Litter was collected on a regular basis from the traps (monthly for most sites in the first year), dried in an oven and weighed separately for the different components (leaves, flowers, fruits, bracts, wood, and miscellaneous items).

Physical environmental data collected weekly at monitoring sites included water temperature, salinity and light attenuation (at reef and seagrass sites only). The program used simple manual data collection protocols including measuring water temperature with a handheld field thermometer (and later with automated loggers), salinity with a handheld refractometer, and light attenuation with a Secchi disk used vertically at reef sites and horizontally at seagrass sites (CARICOMP, 2001). In later years, a sub-set of CARICOMP research stations were also provided with small semi-automated weather stations to record air temperature, wind speed and precipitation on a more continual basis.

\section{Data Management}

The SC contracted a Data Management Center (DMC) at the University of the West Indies, Mona Campus, Jamaica to which all standard data templates were submitted by network members (CARICOMP, 2002b). Data were checked and entered into the CARICOMP database. With the advent of the worldwide web, the 
CARICOMP data were available from the DMC manager through a web site.

\section{KEY FINDINGS OF THE CARICOMP MONITORING PROGRAM}

In this section, we present brief summaries of the major findings of the CARICOMP monitoring program for each of the coastal ecosystems: coral reefs, seagrasses and mangroves; and for the physical environment.

\section{Coral Reefs}

The coral reef monitoring database encompasses data of 40 reef monitoring stations from 21 Caribbean countries (CARICOMP, 1997c) and covers the period between 1992 and 2007 following the sampling protocols in the CARICOMP Level I Protocol (CARICOMP, 2001). Geographical coverage was widespread throughout the region (Figure 1). This period coincided with several major coral mortality events associated with multiple factors including bleaching (Lang et al., 1992; Eakin et al., 2010), disease (Richardson, 1998; Harvell et al., 2007; Cróquer and Weil, 2009), and other disturbances (Hughes, 1994; Jackson et al., 2014) that had a primary role in determining the current status of coral reefs in the Caribbean (Cróquer et al., unpublished).

At the start of the program in 1993-1994 mean coral cover at CARICOMP sites that contributed long time series (915 years, 10 sites widespread throughout the region; Figure 1) was $22.6 \%$ (95\% CI: 15.2-29.9), and mean macroalgal cover was 38.3\% (95\% CI: 26.7-48.2). These results indicate that when CARICOMP started monitoring Caribbean coral reefs, there was a 2:1 macroalgae to coral cover ratio at those sites. At the end of the program, at these sites, mean coral cover was $17.1 \%$ (95\% CI: $15.2-29.8$ ) and macroalgal cover 59.2\% (95\% CI: 48.7-68.9); a 4:1 macroalgae to coral cover ratio. The mean coral cover yearly loss was estimated at $0.49 \%$, whereas the mean algal cover yearly increase was estimated at $1.8 \%$. The largest net loss of live coral cover for particular sites with long-term data sets were recorded at Turrumote reef in Puerto Rico (-23.9\%), Li2 in Colombian San Andrés Island $(-13.6 \%)$ and Cb2 in Carrie Bow Cay, Belize $(-10.6 \%)$. Whereas the largest net increases in coral cover were at Cs1 Venezuela (6.3\%), and at both sites in Discovery Bay, Jamaica (1.53 and 2.24\%) (Cróquer et al., unpublished).

Temporal trends were extremely variable across the Caribbean during the monitoring period with some sites showing relative stability (e.g., Bahamas, Bermuda; Figure 3) or even an increase in live coral cover (e.g., Venezuela, Jamaica, Figure 3) independently of algal cover change. Meanwhile, at other sites, coral cover tended to be inversed to algal cover, although not monotonically through time (Figure 3). Of particular interest is the fact that declines in coral cover seldom occurred with concomitant increases in macroalgal cover (Figure 3). Hence, declining trends in coral cover in the Caribbean region were not necessarily a result of macroalgae proliferation as has been the general impression from many studies (Jackson et al., 2014). No region-wide geographical patterns seem to prevail in coral cover decline (Figure 3); furthermore variation within continental sites (Belize, Panama, Colombia, and Venezuela) or island sites (Barbados, Jamaica, Bermuda, Puerto Rico) is large. The variable responses at the sampling site spatial scale, suggest that both global and local stressors are playing a complex role in Caribbean coral cover decline (Cróquer et al., unpublished).

\section{Seagrasses}

There were three general objectives of the seagrass monitoring program: (1) to determine growth and abundance of seagrasses at specific sites, (2) to evaluate seasonal trends in these measurements, and (3) to compare the static, dynamic and seasonal measurements across all sites. In the beginning of the program, a major goal was the detection of regional and seasonal trends in the structure and functioning of the systems.

At the time the CARICOMP monitoring program began, most seagrass meadows in the Caribbean were not considered to be under threat from human impact: only 30\% (10 out of 33 stations) had received a noticeable human impact; whereas $70 \%$ (23 out of 33 stations) were considered pristine or only slightly impacted. Most sites were in reef lagoons, dominated by the robust climax seagrass Thalassia testudinum (CARICOMP, 1997e, 2001; Kjerfve, 1998).

The first published description of the status of the seagrass meadows detected large regional variation in T. testudinum biomass and growth (CARICOMP, 1997e). This work concluded that the best developed meadows, with highest biomass and primary production, tended to be near mainland and large island areas, whereas small islands with little relief tended to have less developed meadows. Van Tussenbroek et al. (2014) summarizing the results of the seagrass program, also found wide variations in community total biomass $\left(285\right.$ to $>2000 \mathrm{~g}$ dry wt $\mathrm{m}^{-2}$ ) and annual foliar productivity of T. testudinum $(<200$ to $>2000 \mathrm{~g}$ dry wt $\mathrm{m}^{-2}$ ) among sites (Objective 1). A clear latitudinal divide in seasonal variations in T. testudinum leaf productivity was detected, with solar-cycle related intra-annual variations at latitudes $>16^{\circ} \mathrm{N}$, and lack of seasonal trends below this latitude (Objective 2). However, a true regional picture of the ecology of Caribbean seagrass meadows (Objective 3 ) was only partially obtained; for example, the Physicochemical Provinces of the Caribbean defined by Chollett et al. (2012) could not reliably predict either regional variation in biomass or productivity of the seagrasses. Possibly, other environmental conditions should have been monitored, such as nutrients, sediment conditions and associated biota (especially herbivores), to obtain a more accurate regional picture of the ecology of Caribbean seagrass meadows. Hurricanes did not have long-term effects on the welldeveloped seagrass communities at all seagrass stations except one. Collapse of the meadows occurred at two sites (five stations), due to excessive grazing by turtles at Bermuda or a synergistic effect of community shift due to human disturbance followed by sea-urchin grazing and extreme hydrodynamics at Barbados.

Although detection of long-term trends (or degradation) of the seagrass meadows was not included in the initial scope of the study, long-term shifts in the seagrass communities, consistent with expected changes under environmental deterioration (eutrophication and/or decreasing water transparency), were detected in many of seagrass communities 


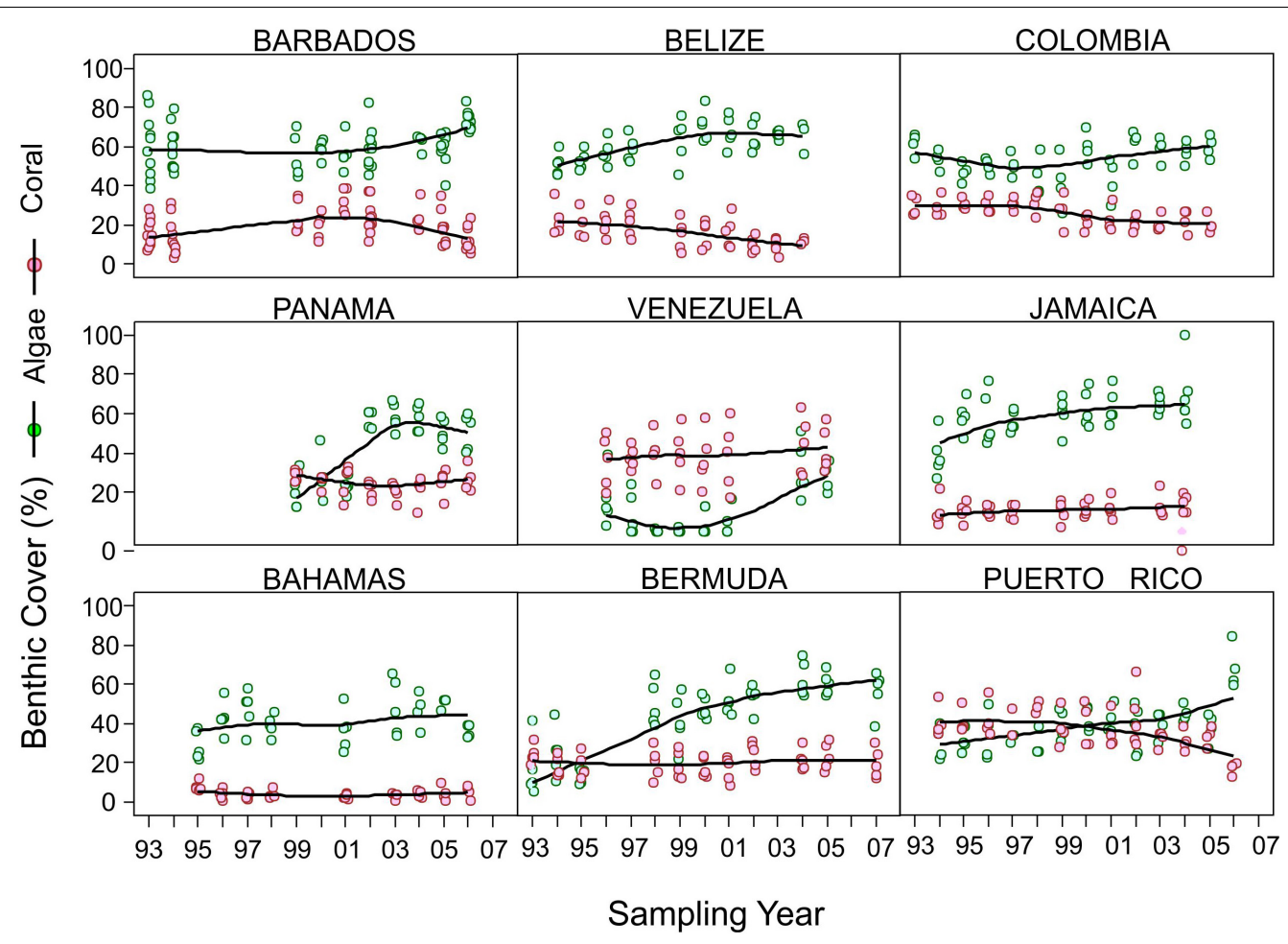

FIGURE 3 | Examples of observed coral and algae benthic cover trends at different CARICOMP sites, including widely separated island and continental sites. Trend is shown as a solid line and corresponds to a non-parametric loess curve (local polynomial regression). Open circles indicate the cover value of sampled transects. Pink indicates coral cover and green indicates algal cover. For spatial location of sites, see Figure 1.

(Van Tussenbroek et al., 2014). These changes show a reverse trend of succession, as indicated by changes in biomass distribution of the seagrass plants, and shift in community composition (Figure 4).

\section{Mangroves}

The main goal of the mangrove monitoring program was to describe differences among sites, seasonal patterns of productivity and changes through time. Changes in structure and function of mangroves are particularly relevant across the Caribbean region in view of the general lack of regional data and the considerable decline in mangrove forest cover globally and within the Caribbean (Ellison and Farnsworth, 1996; Valiela et al., 2001; FAO, 2007; Polidoro et al., 2010). The latter reported a $24 \%$ reduction in mangrove area across the Caribbean region in the 25 years between 1980 and 2005.

Mangrove monitoring at many stations began in 1992 and a total of 21 sites across 18 countries collected data for at least 1 year over the life of CARICOMP (Figure 1). The focus of the monitoring program was the fringing red mangrove Rhizophora mangle, although at some sites the white (Laguncularia racemosa) and the black (Avicennia germinans) mangrove were also present in low abundance and therefore included.

The CARICOMP mangrove sites covered a wide range of environmental conditions across the participating countries, from highly productive estuarine environments, to coastal fringing areas, to over-wash barrier islands (Kjerfve, 1998) and thus forest structure varied enormously among them. The first published description of the CARICOMP mangrove data (1993-1995) indicated a range in mangrove biomass values at 14 sites from 1 to $19 \mathrm{~kg} \mathrm{~m}^{-2}$ (CARICOMP, 1997d). Recent analysis of the full dataset indicates red mangrove densities ranging from 500 to 6000 trees $\mathrm{ha}^{-1}$, tree heights from 1 to $63 \mathrm{~m}$, and seedling densities from 1 to 215 seedlings per $\mathrm{m}^{2}$ across the different sites (Bastidas et al., unpublished).

Mangrove productivity, measured as litter fall, also showed variation among sites, although not as large as the differences in forest structure. Preliminary analysis of the 1993-1995 data indicated a fourfold difference in maximum productivity rates and considerably higher seasonal fluctuation in the northern sites (e.g., Bermuda, 10-fold seasonal change) than in lower latitude sites with a twofold to threefold seasonal variation (CARICOMP, 1997d). This seasonal variation in productivity is also borne out by the full data set (19922014) (Figure 5) (Bastidas et al., unpublished) which indicates mean red mangrove productivity peaks in June through July at an average of $1500 \mathrm{~g} \mathrm{~m}^{-2} \mathrm{yr}^{-1}$ and is lowest in January at $850 \mathrm{~g} \mathrm{~m}^{-2} \mathrm{yr}^{-1}$. Data from a smaller subset of sites also indicates that white and black mangrove productivity is seasonal, with highest mean values of 300 and $550 \mathrm{~g} \mathrm{~m}^{-2} \mathrm{yr}^{-1}$, respectively. White mangrove appears to have a similar seasonal trend to red mangrove, whereas black mangrove productivity peaks later in the year (October) (Figure 5) (Bastidas et al., unpublished). 


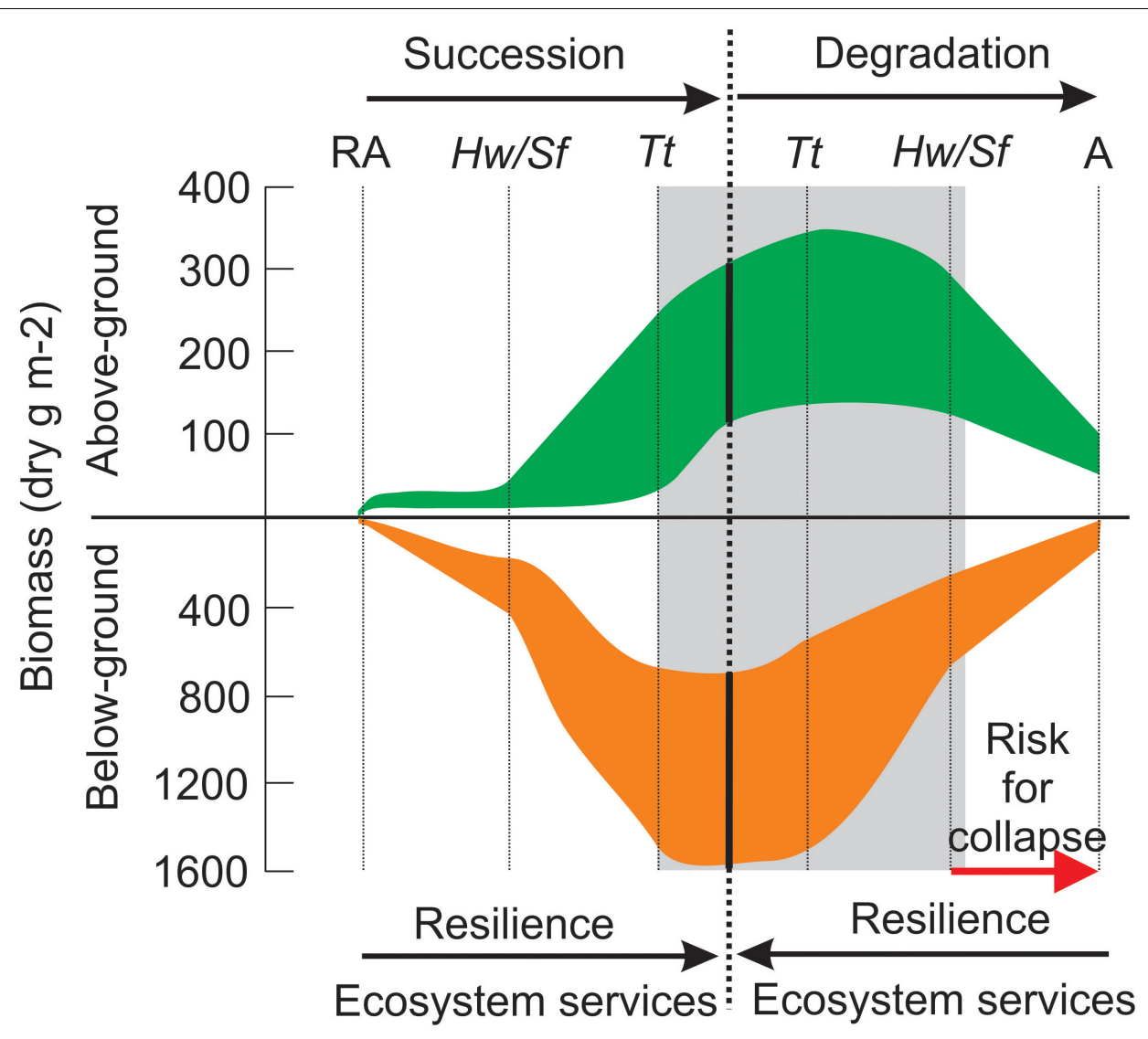

FIGURE 4 | Model of Caribbean seagrass meadow development during succession and degradation as depicted across different CARICOMP sites. Succession initiates with pioneering rhizophytic algae (RA), followed by faster-growing seagrasses Halodule wrightii (Hw) and Syringodium filiforme (Sf), and a vegetation dominated by the robust and slow-growing Thalassia testudinum (Tt) as climax stage (Zieman, 1982; Williams, 1990). The dominant species at each development stage is given, but mixture with species from other stages usually occurs. The reverse tendency occurs during environmental deterioration (eutrophication and/or increasing turbidity), with vegetation consisting of only algae (A: rhizophytic and drift) in extreme conditions. The gray area indicates the range of conditions of the CARICOMP seagrass meadows. Ecosystem services such as primary productivity, stabilization of sediments, habitat provision and carbon sequestration improve during succession, and diminish with increasing deterioration, until they are lost as the system collapses (in synergy with stochastic disturbance).

Analysis of the full dataset (Bastidas et al., unpublished) to examine long-term changes in red mangrove productivity (using seven sites for which there are more than 10 years of data) indicated much less variation over time (years) at any given site than among sites, although their trends differed. At some sites there was a decline in red mangrove productivity (ColombiaChengue, Venezuela-Punta de Mangle and Grand CaymanCentral Swamp); at others there was a slight increase (BermudaHungry Bay, Panama-STRI and Costa Rica-Laguna Gandoca); and at one site productivity was steady through time (Trinidad and Tobago-Bon Accord Lagoon). There does not appear to be any obvious geographical pattern to these different trends, with site characteristics (physical environment of the mangrove) and local stressors such as storms and human disturbance likely being more important than location over the variable time spans of the monitoring at each site.

Overall, mangrove forest structure and productivity showed large contrasts among 21 sites across the Caribbean. Furthermore, deteriorating conditions at particular mangrove sites resulted from a combination of different primary stressors.
Examples include: (a) inability of the forest to recover from the combined effect of storms, sea level rise and/or subsidence; and (b) human activities such as deforestation.

\section{Physical Environment}

Physical environmental data were collected for at least 3 years and up to 22 years at 29 sites in coastal ecosystems (coral reefs, seagrasses, mangroves) in 13 countries across the Caribbean, beginning in 1992 (CARICOMP, 1997b; Chollett et al., 2017).

The most recent basin-scale analysis using the CARICOMP physical database revealed trends in both global and local level stressors of coastal ecosystems (Chollett et al., 2017). A chronic decline in light attenuation (a proxy for deteriorating water quality) over the monitoring period of CARICOMP sites (19922015) was found to be widespread across the Caribbean, despite being caused by local level anthropogenic activities such as increased infrastructural development and other changes in land use. For example, decadal declines in water clarity were reported by $42 \%$ of CARICOMP sites (Chollett et al., 2017). They also reported that decadal increases in the water temperature of 


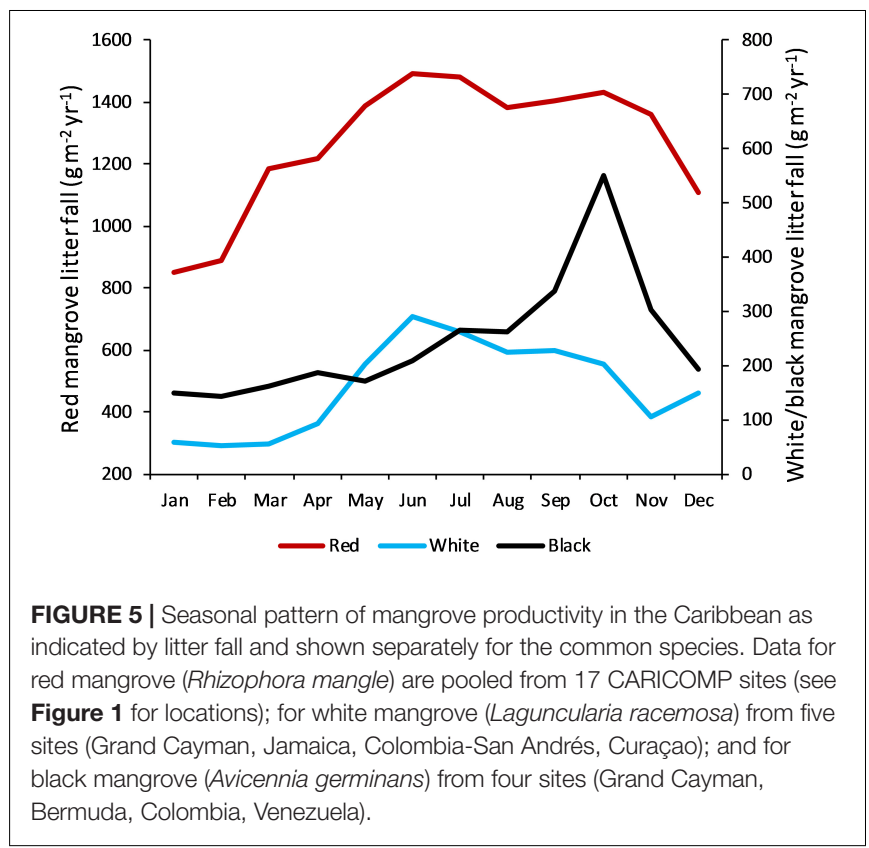

coastal ecosystems could be detected at a further $18 \%$ of sites, which corresponds to the global trend in open ocean water temperatures associated with climate change. The fact climate change-related temperature increases were not detected across all stations is interesting and has several explanations. Probably the most significant factor at most locations was that the data time-series were too short or intermittent to reliably detect long-term change, given the typical seasonal and inter-annual variability. However, it also highlights the importance of local drivers to changes in coastal water temperature, such as local water currents, river inputs, upwelling and water clarity.

\section{LESSONS LEARNED}

In this section, we describe the challenges faced and important lessons learned in design and implementation of the CARICOMP monitoring program over two decades, adding to the preliminary observations of Woodley (1998).

\section{Design and Mobilization}

After a problem is identified monitoring should begin as soon as possible even at a low complexity level. After CARICOMP was established in 1985, we designed ambitious monitoring protocols, but then spent several years trying to raise major funding before any monitoring began. In retrospect we could have begun immediately with simple bucket temperature data. Finally, in 1992 we did roll out the training and began Caribbeanwide monitoring using the low cost, simple methods as outlined in the Level I Methods Manual (CARICOMP, 2001).

As a multi-national, bi-lingual group it is essential to ensure that all members feel equally included. Although a range of nationalities and the two languages were well represented on the $\mathrm{SC}$, and annual meetings were held in different site locations, the early meetings were conducted in English (with only occasional breaks for translation) which resulted in exclusion of Spanishspeaking members. This inequity was subsequently addressed by holding at least some meetings primarily in Spanish (with occasional breaks for translation).

An annual workshop for participants was an essential element, especially given the communication constraints in the 1980s and early 1990s. The meetings generated critical esprit de corps and also provided a valuable opportunity to: share and discuss problems; exchange new information; discuss and refine new methods; and provide additional training. The meetings were also invaluable in strengthening the network by fostering personal relationships between scientists and managers throughout the region and by giving the opportunity for young scientists and students to participate.

The DMC was essential to the survival of the network. Not only did it receive, consolidate and archive all of the data from member institutions (and send reminders to any potential defaulters), but it also gave feedback to all participating sites in the form of network-wide summaries, and acted as a communication center, as well as a source of encouragement and advice. No single site would have had the time to do this work, and provide essential feedback (Linton and Woodley, 1998; CARICOMP, 2002b; Linton and Fisher, 2004).

Sustained monitoring requires significant commitment from participating institutions and individuals. CARICOMP was not able to provide direct financial or human support for monitoring to its member institutions, but did provide, free of charge, an initial shipment of the basic standardized monitoring equipment, the services of the DMC, and an annual workshop for the Site Director. For many participating institutions and individuals, this, along with a strong appreciation of the value of monitoring their coastal ecosystems, was enough to maintain a commitment to the network and monitoring effort over the long-term, or at least for a few years.

Lack of funds constrained all activities. With more funding, more institutions would have been able to maintain Level I monitoring and more would have extended into Level II. Furthermore, we could have considered using more diverse methods including socio-economic monitoring, other educational activities and perhaps worked directly with coastal communities. We now recognize that socio-economic monitoring should be a part of any long-term monitoring program from the start.

In addition to the lack of sufficient funding, most CARICOMP Site Directors, with the exception of a few park and reserve managers, had a background in natural science and were reluctant, at that time, to engage in the social sciences. This reluctance could have been overcome with training in interview techniques and the use of carefully designed protocols and questionnaires.

\section{Monitoring Protocols}

An early lesson was how different coral reefs, seagrass meadows and mangrove forests are across the region, so that finding a standardized methodology that was appropriate and simple across the full range of this variation was a huge challenge. For 
example, there were large differences in site accessibility, density of key indicator organisms, and structural complexity.

Another challenge for many sites, particularly on the small islands, was finding a location where coral reefs, seagrasses and mangroves were all in close proximity. Having sites remote from the research station as well as from each other, complicated the monitoring, the choice of where to set up the weather station such that it was relevant to the sites being monitored, and the time and budget required to access different areas.

A further problem was finding 'pristine' sites, since there were variously disturbed coral reefs, seagrass meadows or mangroves in the Caribbean back in the early 1980s, especially in the small islands. It was therefore accepted that baseline data could be collected from sites variously disturbed by human activities.

The initial methods training in a field workshop setting was very effective and also benefited greatly from the inclusion of ideas from the many participants with different levels of experience and familiarity with different environments.

\section{Coral Reefs}

Chain transects for reef monitoring are labor intensive, requiring divers with good identification skills and patience. We contemplated changing to a video method, which has the added benefit of a permanent visual record. This would have increased the cost but shifted the labor intensiveness to the laboratory. Some sites experimented with this transition, but in reef sites with high rugosity the method was inadequate, due to the bulkiness of available underwater housings at the time which made it very difficult to maintain a perpendicular filming angle across the entire transect. Also, the slow sensor response of the cameras available at the time, to abrupt light intensity changes, meant that the films were of poor resolution and difficult to interpret.

Retrospectively the main difficulty of the CARICOMP chain method was that it requires too much sampling rigor, to obtain useful data for long-term studies in the fixed sites. We found that the precision of the method varied greatly due to observer bias, thus resorted to placing stainless steel nails at fixed distances along each transect to help the observer to position the chain more precisely in repeat surveys. Many sites adopted this technique and the average precision of the coral cover and diversity estimates increased. However, other sites found it impossible to drive nails into the hard rock substrate, or to do so without causing significant damage in the case of coral skeletons weakened by boring sponges.

\section{Seagrasses}

The monitoring methods and site-selection procedure were designed for non-experts. As selection of a "typical" seagrass meadow is subject to bias, the participants were instructed to select two stations at each site: one of them considered to be "typical" for the site, and the other having the "best-developed" seagrass meadow. The variability of the data for the stations within the sites was usually smaller than the variations between sites (Van Tussenbroek et al., 2014). However, the spatial resolution of only two sampling stations is small, and may not reflect the general condition of the whole seagrass meadow at a site. If the latter is the objective of a monitoring program, then wider-scale monitoring protocols are needed. Monitoring programs on a larger spatial scale require different sampling strategies such as visual assessment of abundance along transects, used in various seagrass monitoring programs established after CARICOMP, such as Seagrass Watch (McKenzie et al., 2000), Florida Bay Seagrass Monitoring (Fourqurean et al., 2001) or Seagrass Net (Short et al., 2006). However, it is important to consider that the latter programs are costlier and more labor intensive, potentially limiting the number of participants, especially those from small islands. Thus, when establishing a regional monitoring program, the benefits of either higher local resolution or wider geographical coverage should be carefully considered.

The CARICOMP protocol consisted of biannual collection of small samples $(10 \times 20 \mathrm{~cm}$ quadrats for leaf growth, $N=4-6$, and core diameter $15-20 \mathrm{~cm}, N=2-4$ for total community biomass) in the typical and well-developed meadow sections at each site. Determination of biomass is likely more objective than estimation of cover or abundance, but it is destructive; thus, not suitable for meadows which are in a precarious condition. For example, at Barbados, core sampling was discontinued when the meadows suffered degradation, and at Florida Keys, core samples were never taken all for this reason. In such cases, $0.5 \times 0.5 \mathrm{~m}$ quadrats were used to estimate short shoot density by species, and an index of epiphytic cover and grazing damage. However, the ratio of above substrate to total biomass of the seagrasses obtained from the core-samples was a good predictor of change (Figure 4). In addition, small samples may not always be representative for each vegetation group; this especially applied to less-abundant and more irregular distributed components such as the macroalgae. Larger non-destructive samples (observation of cover, abundance or density in larger quadrats) are necessary in such cases. In the Caribbean, the macroalgae are equally important or possibly better indicators of change in the environment than the seagrasses (Van Tussenbroek et al., 2014), thus representative sampling of this plant group is important and should be included in the future.

The low-cost methods of CARICOMP seagrass monitoring were sufficient to detect long-term shifts in the communities, and the recent published manuscript (Van Tussenbroek et al., 2014) was the first report on region-wide deterioration of the seagrasses throughout the Caribbean. However, it was unfortunate that water column nutrients were not included in the seagrass protocol from the beginning (Chollett et al., 2017). The causes for long-term shifts in seagrass communities had to be derived from other studies relating changes in the seagrasses and community to changes in nutrient input into the environment (Van Tussenbroek et al., 2014).

\section{Mangroves}

The monitoring protocol for mangrove forests, although relatively simple and straight forward, turned out to be very difficult and/or time-consuming to conduct in some mangrove 
locations due to the enormous variation in substrate, tree density and tree height among the sites across the Caribbean. For example, at several sites the red mangrove prop roots were so dense, that accessing and laying out the plots was extremely difficult, involving climbing from one tree to the next which took many hours in the initial set up and subsequent data collection exercises. In some sites the trees were much taller than the telescopic rods and using the alternative clinometer to measure height was not practical because of the tree density and thickness of the canopy which restricted visibility. As such, at these sites the tree heights were simply estimated and the errors magnified in calculations of biomass and volume.

In some sites measuring litter fall was a great challenge. For example, the Barbados-Graeme Hall site with no tidal flushing and therefore no export of leaf litter, the floor litter was so deep it was difficult to know how deep to sample. Furthermore, collection of litter fall was compromised by consistent removal of traps by local children to use as fishing nets. This meant that it was extremely challenging to fulfill this part of the protocol.

Counting and measuring seedlings in the small subplots was incredibly time consuming in cases with high abundances of 100300 plants per subplot. This resulted in fewer subplots being monitored and an absence of permanently marked seedlings. Permanent marking of the trees was essential for consistent monitoring of individual trees over the long-term.

Accessibility was another issue, with some mangrove sites that were far from shore and needed boat access and accommodation on offshore islands to complete the surveys. Others were far from the institutional base on land, requiring several hours to reach by road, whilst there were others where the mud was so soft, it was very difficult to work in. This contributed greatly to the reduced frequency and length of sampling at many sites.

\section{Physical Parameters}

One of the greatest challenges across most member institutions was the time commitment required to manually sample physical parameters on a daily (at the research station site) or even a weekly (at each of the coastal ecosystem stations) basis. As a result, the CARICOMP physical parameter database, in particular, suffers from discontinuity caused by the enormous variation among sites in the frequency and time-scale of data collection. This was especially problematic for member sites whose monitoring stations were remote and often far apart from each other also. This challenge (at least in the case of recording water temperature) was overcome when new technology, allowing continuous recording by relatively inexpensive temperature loggers was introduced, since the loggers could be installed in situ and collected and read at yearly intervals. This was not the case, however, with salinity.

Although automated weather stations and dedicated computers were provided to some of the sites, the technology was not particularly simple, and most stations were unable to maintain the devices over the long-term. Problems included security of the instruments, the fact that spare parts were not available locally, and the computer hardware/software used to download the data quickly became outdated and were not replaced. Another issue with the weather stations was the location, given the high local variability in wind and precipitation particularly, and the fact that the weather stations were often remote from one or more of the coastal ecosystems being monitored.

\section{Data Handling and Analysis}

Data entry at each site into fixed template spreadsheets facilitated checking for errors and reduced the workload at the DMC. The spreadsheet templates ensured uniformity of style and units at data entry, and simple calculations were automated to prevent the otherwise inevitable human errors. At the DMC, spreadsheet data were entered into a relational database. This two-stage system has advantages of simplicity and flexibility, making the best use of each data storage medium. One of the challenges, however, was the fast pace of change in computer software and technology, especially methods of data storage and transmission. This resulted in the loss of datasets at some laboratories as computers and/or storage disks became redundant, and software changed. Likewise, the fixed template was, in the end, very cumbersome and not updated to benefit from the vast improvements that occurred in available software over the years.

As CARICOMP was based at many sites across the Caribbean, there were unavoidable problems associated with multiple observers. In some cases, the site data were extremely variable, particularly in countries that changed observers often and/or could not dedicate the time or resources to train and calibrate observers. There were other examples however, where inter- and intra-variability among observers was properly managed. Our solution to this problem was twofold: (1) reduction of observers involved with local monitoring activities at each site, and (2) constant calibration among observers, particularly when new people entered the program.

If sampling was based on cover estimates, as was done for the coral reefs, the magnitude of the sampling error induced by different observers or sampling in suboptimal conditions could have been better controlled by checking for data consistency, immediately after the sampling. For example, comparing coral cover estimates by transect with those of previous years (e.g., coral cover does not generally change as fast as algal cover) would have allowed for detection of sampling errors in time for the sampling to be redone within the same sampling season. These errors could not be corrected by the DMC in a timely manner, since datasets were not submitted in real time. The potential for observer bias required careful analysis of patterns and trends to identify and eliminate unreasonable extreme values.

Many laboratories simply lacked the capacity to maintain the monitoring protocols in one or all of the ecosystems over the duration of the CARICOMP program, which resulted in multiple and often major temporal gaps in the database. This negated the usefulness of the time-series at many sites and complicated the regional data analyses.

Open access to the data was a goal from the start. However, this created proprietary concerns when the data were used by third parties without proper acknowledgment, and so the members imposed an embargo to allow time for members within the network to publish data first. 


\section{SUMMARY CONCLUSION}

In this section, we review the benefits of CARICOMP to different stakeholders in the region and how the program has contributed to coastal ecosystem science in the Caribbean.

In general CARICOMP has played a central role in building scientific expertise and access to technology across the Caribbean. For almost two decades, hundreds of participating students from different universities across the region had the opportunity to complete their theses, to build their careers, improve their skills as marine scientists and to use the network to establish research cooperation and find opportunities in postgraduate programs within member institutions.

The in situ monitoring program for physical parameters, although simple, was unique in the Caribbean region not only for its broad geographical coverage, but also for the length of time it continued. The dataset has been useful for examining trends in support of local studies at many of the CARICOMP sites (CARICOMP, 2002a; see also Table 1), has provided in situ measurements in support of further development of more accurate ex situ (e.g., satellite derived) parameter estimates, has provided baseline measurements across the region from the early 1990s (CARICOMP, 1997b; Alcolado et al., 2001) and has allowed researchers to examine basin-scale trends over two decades (Chollett et al., 2017).

\section{Contributions to Coral Reef Science}

The CARICOMP coral reef monitoring program started in a decade characterized by unprecedented and rapid loss of coral cover, biodiversity and loss of structural complexity across the Wider Caribbean (CARICOMP, 1997c, 2002a). These declines had profound impacts on the structure and functioning of these ecosystems (Hughes, 1994). While the value of monitoring programs was acknowledged long before the CARICOMP program started, efforts to describe long-term temporal changes of coral reefs were restricted to a limited number of sites in a few Caribbean countries (e.g., in Curaçao, Aruba and Bonaire: de Bakker et al., 2016, 2017).

Despite technical difficulties, the legacy of the CARICOMP coral-monitoring program is undisputable. Firstly, the CARICOMP network was the first to produce a database of coral reefs in the Caribbean that combined long-term monitoring from local to regional spatial scales. This approach opened the door for other monitoring initiatives such as AGRRA (Atlantic and Gulf Rapid Reef Assessment), Reef Check and the GCRMN-Caribbean (Global Coral Reef Monitoring Network).

Secondly, CARICOMP presented synthesis papers in almost every International Coral Reef Symposium between 1996 and 2016. CARICOMP's policy of open access to the data assisted the publication of many studies assessing the status of Caribbean reefs including the often-cited Gardner et al. (2003) and more recently, the synthesis report of Caribbean coral reefs by Jackson et al. (2014). We also published our results for managers, park rangers, NGO's and local governments (e.g., Kjerfve, 1998) (Table 1). In this regard, the network brought together different stakeholders from various Caribbean countries to increase awareness about coral reef conservation.
The legacy of CARICOMP as a coral reef monitoring program was twofold: (1) it was the first program to describe the long-term trajectories of coral reef ecosystems at a regional scale, and (2) it maintained a joint monitoring effort among institutions of 21 Caribbean countries with different cultures and political systems.

\section{Contributions to Seagrass Science}

Scientific research into seagrass ecosystems has a relatively short tradition. The first international scientific meeting on seagrasses was organized in 1973, when very little was known about seagrasses in general, and particularly from the tropical regions (McRoy and Helfferich, 1977). In the Caribbean, seagrass meadows (and mangroves) have not received the same attention as the coral reefs, and their importance as a coastal habitat often was (and still is) ignored. Including these ecosystems in CARICOMP was central to the integrative coastal vision of this program and the CARICOMP seagrass monitoring program was the first seagrass monitoring network that allowed comparison of seagrass biomass, productivity and community composition over a large spatial gradient using a common protocol.

The contribution of the CARICOMP seagrass monitoring program has been important in this region, not only because it produced a general picture of the status of the seagrass meadows across the Caribbean, but also because it involved research teams in the study of seagrasses, resulting in various local studies of Caribbean seagrass meadows (Table 1). At some sites CARICOMP seagrass sampling was incorporated in field and laboratory studies by other investigators and students, increasing awareness and knowledge of seagrass meadows across the Caribbean, and encouraging further study of this ecosystem.

At present, seagrasses are as important for the coastal ecosystem services as other coastal systems, such as salt marshes, mangroves and coral reefs (Barbier et al., 2011). The impact of ongoing human activities on the marine environment, in synergy with natural disturbances such as hurricanes or grazing, could push the resilience of the coastal systems to collapse (Grech et al., 2012; Maxwell et al., 2017). A recent potential threat to the seagrass meadows across the Caribbean is the beach stranding of massive quantities of drifting Sargassum spp. (Franks et al., 2011; Smetacek and Zingone, 2013), that cause Sargassum 'brown tides' that locally eradicate near-shore seagrass meadows and may induce long-term gradual changes to the coastal waters (Van Tussenbroek et al., 2017).

The legacy of CARICOMP as a seagrass monitoring program is (1) the attention it has drawn to this important, and previously ignored, ecosystem in the region, and (2) the regional baseline data collected and the monitoring protocols that have been established, setting the stage for future monitoring of the condition of those seagrass meadows, which is now even more urgent than when the CARICOMP program began.

\section{Contributions to Mangrove Science}

There has been considerably less emphasis on scientific research into mangrove ecosystems than coral reefs generally, and there are no regional monitoring programs for mangrove forests in the Caribbean, although there are some national programs (Wilson, 2017) and several global/regional mapping and assessment 
TABLE 1 | Studies at local sites using results of the CARICOMP monitoring program in coral reefs (CR), seagrasses (SG), and Mangroves (M).

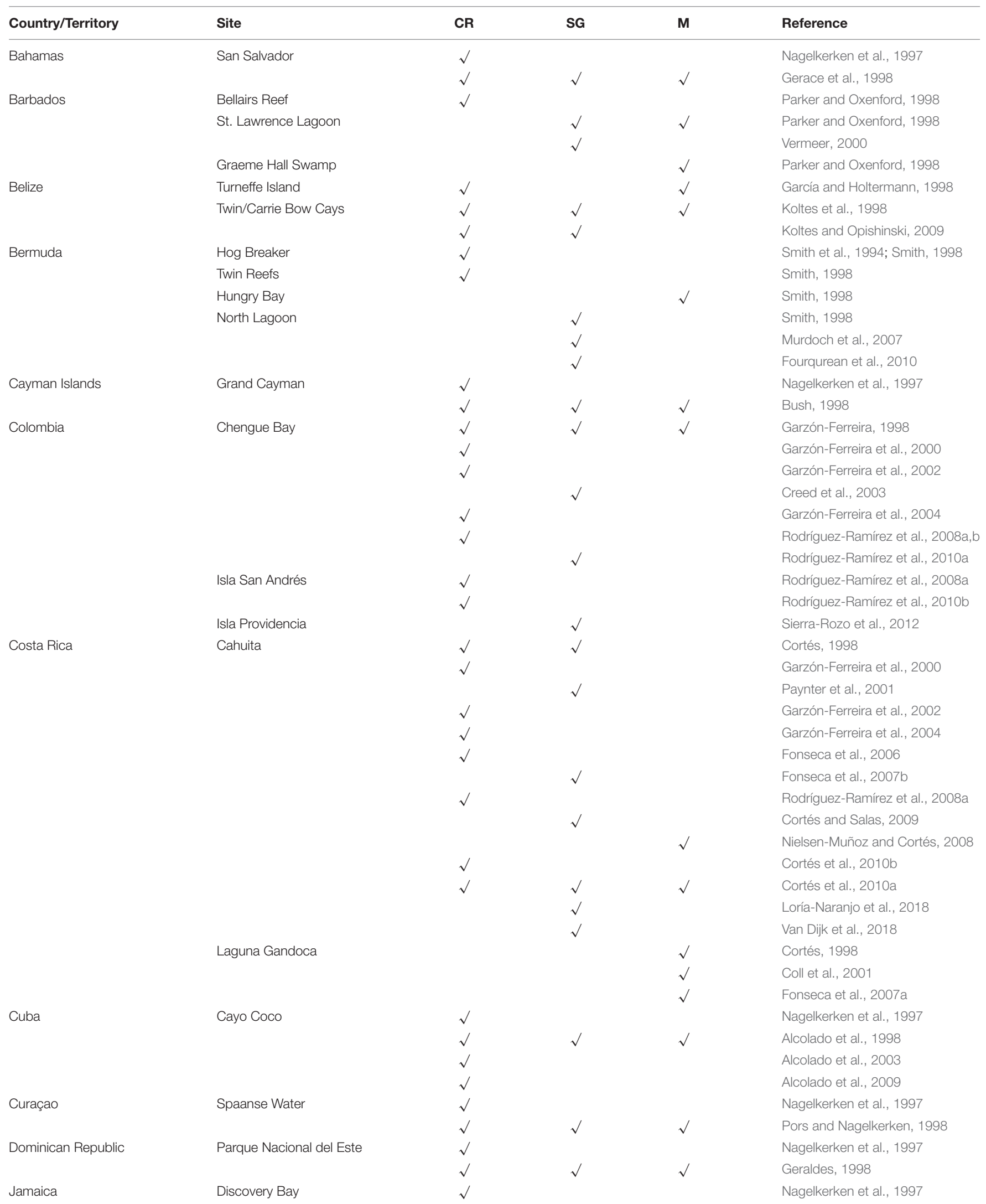


TABLE 1 | Continued

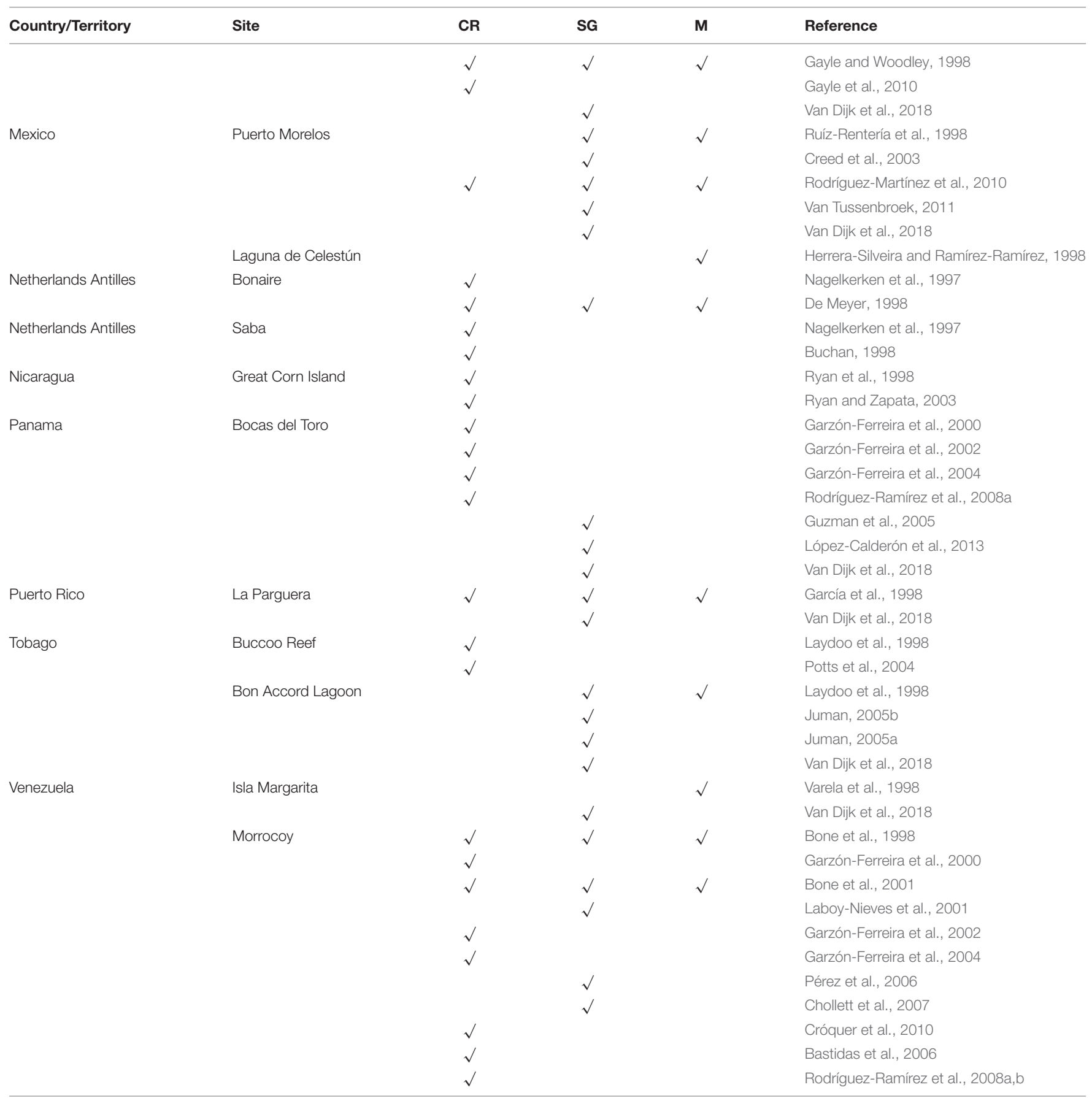

efforts (e.g., Ellison and Farnsworth, 1996; FAO, 2007; Spalding et al., 2010; Giri et al., 2011; Webber et al., 2016). As such, CARICOMP has made a unique and useful contribution to the knowledge of this much overlooked but important ecosystem in the region, as the first long-term regional mangrove monitoring program. CARICOMP has provided baseline data on mangrove forest structure and information on seasonal variation in productivity for sites widely dispersed across the Caribbean. Continuous time-series data were also collected by several CARICOMP member institutions. These baseline and the time-series data of forest structure and productivity, as well as the physical parameters measured, will be particularly important in the detection and improved understanding of the impacts of future climate change on mangrove ecosystems in this region (Farnsworth et al., 1996). A further legacy of the CARICOMP program for mangroves is the establishment of a monitoring protocol and a cadre of Caribbean scientists trained in the standardized methods, that have set the stage 
for ongoing study and assessment of this valuable ecosystem (Table 1).

\section{Comparison of CARICOMP With Other Monitoring Programs}

CARICOMP was one of the few monitoring programs in the world and the only one that studied structure and functioning of the inter-dependent tropical coastal-marine ecosystems, mangroves, seagrasses and coral reefs, together with environmental data. Given the high public profile of coral reefs and the increasing global impact of coral bleaching, reef monitoring programs have become prominent in the past few years. The Global Coral Reef Monitoring Network (GCRMN) ${ }^{1}$ began in 1996 and remains active in the Caribbean region ${ }^{2}$. The Atlantic and Gulf Rapid Reef Assessment (AGRRA) Program ${ }^{3}$ began as a one-time reef evaluation protocol but is now dedicated to long-term monitoring. Modifications of the original AGRRA methodology are being used widely in the region ${ }^{4}$ and the data are freely accessible.

There are two main seagrass monitoring networks, the global Seagrass-Watch started in $1999^{5}$ and more than 25 countries participate but only one site in the Caribbean at St. Croix, United States Virgin Islands. The other seagrass monitoring program, SeagrassNet ${ }^{6}$, that started in 2001, is active mainly in the Western Pacific with Belize being the only Caribbean participant.

There are no international cooperative mangrove monitoring programs. Some countries, for example Mexico, have their own programs, coordinated by the National Commission for the Knowledge and Use of Biodiversity (Comisión Nacional para el Conocimiento y Uso de la Biodiversidad, $\mathrm{CONABIO}^{7}$ ).

CARICOMP has been the longest lasting monitoring program. It is still in use today at sites where the data are important locally for science, management and training such as in Colombia, Venezuela, Barbados, and Costa Rica.

\section{Concluding Remarks}

In the lifetime of the oldest co-author of this paper, the human population of the world has increased more than three times from 2.3 billion and it has more than doubled from 3.7 to almost 8 billion in the last 50 years since we first noted disturbing evidence of decline of Caribbean coastal ecosystems. Atmospheric $\mathrm{CO}_{2}$, linked to climate change and ocean warming and acidification, has exceeded 400 ppm in spite of the 2015 COP21 global treaty of nations pledging to reduce emissions to negotiated targets. Added to these global threats is the ever increasing pollution of coastal and oceanic waters, and the relentless demand of a growing population for ocean resources.

\footnotetext{
${ }^{1}$ https://www.icriforum.org/gcrmn

${ }^{2}$ http://www.car-spaw-rac.org/?The-GCRMN-Caribbean, 637

${ }^{3}$ http://www.agrra.org/about-us/

${ }^{4}$ http://www.agrra.org/our-partnerships/

${ }^{5} \mathrm{http} / / /$ www.seagrasswatch.org/participate.html

${ }^{6} \mathrm{http}: / /$ www.seagrassnet.org

${ }^{7}$ www.biodiversidad.gob.mx/v_ingles/ecosystems/mangroves/monitoring Program1.html
}

Cooperative monitoring of Caribbean coastal ecosystems as reported herein by CARICOMP and as well as other organizations have documented the impact of these human disturbances and helped to identify the drivers. However, too often our work ends at a publication or a report. We must take our results directly to policy-makers in a more effective way. The organization of Caribbean marine laboratories developed by CARICOMP over many years is a major resource to facilitate this outreach. They are the repositories of knowledge and history of coastal regions of the Caribbean and have direct links to their respective governments. The most important sectors of the economies of the nations of the Caribbean are tourism and fisheries. Fisheries have great cultural importance, but the Caribbean has the most tourism dependent economies in the world. The economic valuation of ecosystem services could be the wedge that captures the attention of governments.

We urge our CARICOMP marine laboratory partners to: (1) Seek improved networking of regional scientific, management, and conservation scientific organizations; (2) Develop relationships with their respective governments and keep them informed of the results of scientific studies on the local and regional ecological and economic impact of coastal pollution, over-fishing, climate change and ocean acidification; (3) Get involved and advise existing programs in regional ocean governance such as the Caribbean Large Marine Ecosystem (CLME) project; (4) Support coordinated, networked ocean observing and research based at marine laboratories and other coastal management and conservation institutions (Ogden et al., 2014).

There is growing evidence that if we successfully expand our governance of human disturbances from national boundaries to the larger scale of ocean processes, we can build ecosystem resilience. Whether this works or not, the effort will not be wasted. No matter the results of the demographic and ecological changes that are ahead, we will continue to depend upon ocean resources and will be sustained by ocean biodiversity and ecosystem services and its contributions to the maintenance of the global ocean-atmosphere system.

\section{AUTHOR CONTRIBUTIONS}

JO was responsible for the original concept of CARICOMP and for assembling the Steering Committee. JO, EJ-D, and JC were members of the Steering Committee that raised program funding, developed the standardized protocols, and guided the science throughout the long-term monitoring. All authors were involved in writing this review.

\section{ACKNOWLEDGMENTS}

We thank Marc Steyaert of the UNESCO Coastal Marine Program (later, Coastal Regions and Small Islands) for recognizing a scientific opportunity and funding the founding workshops and much of the first decade of the CARICOMP program. The Steering Committee: Co-Chairs, 
E. Jordán-Dahlgren and J. Ogden, J. Cortés-Núñez, J. GarzónFerreira, I. Goodbody, B. Kjerfve, P. Penchaszadeh, E. Ramcharan, W. Wiebe, J. Woodley, and J. Zieman negotiated and implemented funding, administrative and logistical arrangements.

The administrations of the many Caribbean marine laboratories and institutions who formally joined the program over the years contributed facilities and personnel, which matched and in some cases surpassed our fund raising. We depended on the Site Directors, who worked diligently to collect data and who made our annual meetings educational, productive and great fun. Most of their names appear as co-authors of the publications listed in the "References" section.

The West Indies Laboratory of Fairleigh Dickinson University in St. Croix hosted CARICOMP from 1982 to 1987 and E. Gladfelter helped organize meetings and write reports. The Florida Institute of Oceanography (FIO) of the University of South Florida was the administrative and logistical center for the program from 1988 to 2010. We thank D. Milliken, S. Vargo,

\section{REFERENCES}

Alcolado, P. M., Alleng, G., Bonair, K., Bone, D., Buchan, K., Bush, P. G., et al. (2001). The Caribbean coastal marine productivity program (CARICOMP). Bull. Mar. Sci. 69, 819-829.

Alcolado, P. M., Caballero, H., and Perera, S. (2009). Tendencia del cambio en el cubrimiento vivo por corales pétreos en los arrecifes coralinos de Cuba. Ser. Oceanol. 5, 1-14.

Alcolado, P. M., Claro-Madruga, R., Menéndez-Macías, G., García-Parrado, P., Martínez-Daranas, B., and Sosa, M. (2003). "The Cuban coral reefs," in Latin American Coral Reefs, ed. J. Cortés (Amsterdam: Elsevier), 53-75. doi: 10.1016/ B978-044451388-5/50004-7

Alcolado, P. M., Menéndez, F., García-Parrado, P., Zuñiga, D., MartínezDarana, B., Losa, M., et al. (1998). "Cayo coco, sabana-camagüey archipelago, cuba," in CARICOMP-Caribbean Coral Reef, Seagrass and Mangrove Sites, ed. B. Kjerfve (Paris: UNESCO), 221-228.

Alvarez-Filip, L., Dulvy, N. K., Gill, J. A., Côté, I. M., and Watkinson, A. R. (2009). Flattening of Caribbean coral reefs: region- wide declines in architectural complexity. Proc. R. Soc. Biol. Sci. 276, 3019-3025. doi: 10.1098/rspb.2009.0339

Barbier, E. B., Hacker, S. D., Kennedy, C., Koch, E. W., Stier, A. C., and Silliman, B. R. (2011). The value of estuarine and coastal ecosystem services. Ecol. Monogr. 81, 169-193. doi: 10.1890/10-1510.1

Bastidas, C., Croquer, A., and Bone, D. (2006). "Shift of dominant species after a mass mortality on a Caribbean reef," Proceedings of the 10th International Coral Reef Symposium, Okinawa, 989-993.

Bone, D., Cróquer, A., Klein, E., Pérez, D., Losada, F., Martín, A., et al. (2001). Programa CARICOMP: monitoreo a largo plazo de los ecosistemas marinos del Parque Nacional Morrocoy, Venezuela. Interciencia 26, 457-462.

Bone, D., Pérez, D., Villamizar, A., Penchaszadeh, P., and Klein, E. (1998). "Parque Nacional Morrocoy, Venezuela," in CARICOMP-Caribbean Coral Reef, Seagrass and Mangrove Sites, ed. B. Kjerfve (Paris: UNESCO), 151-159.

Buchan, K. (1998). "Saba, Netherlands Antilles," in CARICOMP-Caribbean Coral Reef, Seagrass and Mangrove Sites, ed. B. Kjerfve (Paris: UNESCO), 187-194.

Bush, P. G. (1998). "Grand Cayman, British West Indies," in CARICOMPCaribbean Coral Reef, Seagrass and Mangrove Sites, ed. B. Kjerfve (Paris: UNESCO), 34-42.

CARICOMP (1997a). "Caribbean Coastal Marine Productivity (CARICOMP): a research and monitoring network of marine laboratories, parks, and reserves," in Proceedings of the 8th International Coral Reef Symposium, Vol. 1, Panamá, 641-646.

CARICOMP (1997b). "Meteorological and oceanographic characterization of coral reef, Seagrass and mangrove habitats in the Wider Caribbean," in Proceedings of the 8th International Coral Reef Symposium, Vol. 1, Panamá, 657-662.
D. Haynes, R. Erdmann, and R. Walker for administration of a patchwork of grant and contract support and for facilitating numerous international meetings and complex logistics. The University of the West Indies, Centre for Marine Sciences (CMS) in Kingston provided operational and logistical support for the Data Management Center (later, Caribbean Coastal Data Centre) and we thank CMS Directors I. Goodbody, J. Woodley, G. Warner, D. Webber and data managers D. Linton and M. Ford.

The John D. and Catherine T. MacArthur Foundation, Phase I (1991-1994) and Phase II (1995-1999), provided core funding for CARICOMP. We are grateful for the support and advice of Dan Martin, Director of the Environment Program. Supplemental funding was provided by: (1) Summit Fund of Washington (Roger and Vicki Sant); (2) Henry Foundation (Wolcott Henry and Angel Braestrup); (3) United States National Science Foundation; (4) Coral Reef Initiative, United States Department of State; (5) Coral Reef Program (Karen Koltes), Office of Insular Affairs, United States Department of the Interior; and (6) UNEP Caribbean Environment Program.

CARICOMP (1997c). "Physiography and setting of CARICOMP sites: a pattern analysis," in Proceedings of the 8th International Coral Reef Symposium, Vol. 1, Panamá, 647-650.

CARICOMP (1997d). "Structure and productivity of mangrove forests in the Greater Caribbean region," in Proceedings of the 8th International Coral Reef Symposium, Vol. 1, Panamá, 669-672.

CARICOMP (1997e). "Variation in ecological parameters of Thalassia testudinum across the CARICOMP network," Proceedings of the 8th International Coral Reef Symposium, Vol. 1, Panamá, 663-668.

CARICOMP (2002a). "Status and temporal trends at CARICOMP coral reef sites," in Proceedings of the 9th International Coral Reef Symposium, Vol. 1, Bali, 325-330.

CARICOMP (2002b). "The Caribbean coastal marine productivity program (CARICOMP) Database: potential for data mining and comparisons of Caribbean-wide datasets," in Proceedings of the 9th International Coral Reef Symposium, Vol. 2, Bali, 901-908.

CARICOMP (2001). Caribbean Coastal Marine Productivity (CARICOMP) Methods Manual: Levels 1 and 2. Manual of Methods for Mapping and Monitoring of Physical and Biological Parameters in the Coastal Zone of the Caribbean. Kingston: CARICOMP, 51.

Chollett, I., Bone, D., and Pérez, D. (2007). Effects of heavy rainfall on Thalassia testudinum beds. Aquat. Bot. 87, 189-195. doi: 10.1016/j.aquabot.2007.05.003

Chollett, I., Collin, R., Bastidas, C., Cróquer, A., Gayle, P. M. H., JordánDahlgren, E., et al. (2017). Widespread local chronic stressors in Caribbean coastal habitats. PLoS One 12:e0188564. doi: 10.1371/journal.pone.0188564

Chollett, I., Mumby, P. J., Muller-Karger, F. E., and Hu, C. (2012). Physical environments of the Caribbean. Limnol. Oceanogr. 57, 1233-1244. doi: 10.4319/ lo.2012.57.4.1233

Coll, M., Fonseca, A. C., and Cortés, J. (2001). El manglar y otras asociaciones vegetales de la laguna Gandoca, Limón, Costa Rica. Rev. Biol. Trop. 49(Suppl. 2), 321-329.

Cortés, J. (1998). "Cahuita and laguna Gandoca, Costa Rica," in CARICOMPCaribbean Coral Reef, Seagrass and Mangrove Sites, ed. B. Kjerfve (Paris: UNESCO), 107-113.

Cortés, J., Fonseca, A. C., Nivia-Ruiz, J., Nielsen-Muñoz, V., Samper-Villarreal, J., Salas, E., et al. (2010a). Monitoring coral reefs, seagrasses and mangroves in Costa Rica (CARICOMP). Rev. Biol. Trop. 58(Suppl. 3), 1-22.

Cortés, J., Jiménez, C. E., Fonseca, A. C., and Alvarado, J. J. (2010b). Status and conservation of coral reefs in Costa Rica. Rev. Biol. Trop. 58(Suppl. 1), 33-50. doi: $10.15517 /$ rbt.v58i1.20022

Cortés, J., and Salas, E. (2009). "Seagrasses," in Marine Biodiversity of Costa Rica, Central America, eds I. S. Wehrtmann, and J. Cortés (Berlin: Springer), 119-122. doi: 10.1007/978-1-4020-8278-8_6 
Creed, J. C., Phillips, R. C., and Van Tussenbroek, B. I. (2003). "Seagrasses of the Caribbean," in World Atlas of Seagrasses, eds E. P. Green, and F. T. Short (London: University of California Press), 234-242.

Cróquer, A., Debrot, D., Klein, E., Kurten, M., Rodríguez, S., and Bastidas, C. (2010). What can two years of monitoring tell us about Venezuelan coral reefs? The Southern Tropical America node of the Global Coral Reef Monitoring Network (STA-GCRMN). Rev. Biol. Trop. 58(Suppl. 1), 51-65.

Cróquer, A., and Weil, E. (2009). Changes in Caribbean coral disease prevalence after the 2005 bleaching event. Dis. Aquat. Organ. 87, 33-43. doi: 10.3354/ dao02164

de Bakker, D. M., Meesters, E. H., Bak, R. P., Nieuwland, G., and van Duyl, F. C. (2016). Long-term shifts in coral communities on shallow to deep reef slopes of Curaçao and Bonaire: are there any winners? Front. Mar. Sci. 3:247. doi: 10.3389/fmars.2016.00247

de Bakker, D. M., van Duyl, F. C., Bak, R. P. M., Nugues, M. M., Nieuwland, G., and Meesters, E. H. (2017). 40 years of benthic community change on the Caribbean reefs of Curaçao and Bonaire: the rise of slimy cyanobacterial mats. Coral Reefs 36, 355-367. doi: 10.1007/s00338-016-1534-9

De Meyer, K. (1998). "Bonaire, Netherlands Antilles," in CARICOMP-Caribbean Coral Reef, Seagrass and Mangrove Sites, ed. B. Kjerfve (Paris: UNESCO), 141-150.

Eakin, C. M., Morgan, J. A., Heron, S. F., Smith, T. B., Liu, G., Alvarez-Filip, L., et al. (2010). Caribbean corals in crisis: record thermal stress, bleaching, and mortality in 2005. PLoS One 5:e13969. doi: 10.1371/journal.pone.0013969

Ellison, A. M., and Farnsworth, E. J. (1996). Anthropogenic disturbance of Caribbean mangrove ecosystems: past impacts, present trends, and future predictions. Biotropica 28, 549-565. doi: 10.2307/2389096

FAO (2007). The World's Mangroves: 1980-2005. FAO Forestry Paper No. 153. Rome: FAO, 77.

Farnsworth, E. J., Ellison, A. M., and Gong, W. K. (1996). Elevated $\mathrm{CO}_{2}$ alters anatomy, physiology, growth, and reproduction of red mangrove (Rhizophora mangle L.). Oecologia 108, 599-609. doi: 10.1007/BF00329032

Fonseca, A. C., Cortés, J., and Zamora, P. (2007a). Monitoreo del manglar de Gandoca, Costa Rica (Sitio CARICOMP). Rev. Biol. Trop. 55, 23-31.

Fonseca, A. C., Nielsen, V., and Cortés, J. (2007b). Monitoreo de pastos marinos en Perezoso, sitio CARICOMP en Cahuita, Costa Rica. Rev. Biol. Trop. 55, 55-66.

Fonseca, A. C., Salas, E., and Cortés, J. (2006). Monitoreo del arrecife coralino Meager Shoal, Parque Nacional Cahuita (sitio CARICOMP). Rev. Biol. Trop. 54, 755-763. doi: 10.15517/rbt.v54i3.12774

Fourqurean, J. W., Manuel, S., Coates, K. A., Kenworthy, W. J., and Smith, S. R. (2010). Effects of excluding sea turtle herbivores from a seagrass bed: overgrazing may have led to loss of seagrass meadows in Bermuda. Mar. Ecol. Prog. Ser. 419, 223-232. doi: 10.3354/meps08853

Fourqurean, J. W., Willsie, A., Rose, C. D., and Rutten, L. M. (2001). Spatial and temporal pattern in seagrass community composition and productivity in south Florida. Mar. Biol. 138, 341-354. doi: 10.1007/s002270000448

Franks, J., Johnson, D., Ko, D.-S., Sanchez-Rubio, G., Hendon, R., and Lay, M. (2011). Unprecedented influx of pelagic Sargassum along Caribbean island coastlines during 2011. Gulf Caribb. Fish. Inst. 64, 6-8.

García, E., and Holtermann, K. (1998). "Calabash Caye, Turneffe Islands Atoll, Belize," in CARICOMP-Caribbean Coral Reef, Seagrass and Mangrove Sites, ed. B. Kjerfve (Paris: UNESCO), 67-78.

García, J. R., Schmitt, C., Heberer, C., and Winter, A. (1998). "La Parguera, Puerto Rico, USA," in CARICOMP-Caribbean Coral Reef, Seagrass and Mangrove Sites, ed. B. Kjerfve (Paris: UNESCO), 195-212.

Gardner, T. A., Côté, I. M., Gill, J. A., Grant, A., and Watkinson, A. R. (2003). Long-term region-wide declines in Caribbean corals. Science 301, 958-960. doi: $10.1126 /$ science. 1086050

Garzón-Ferreira, J. (1998). "Bahía de chengue, parque natural tayrona, Colombia," in CARICOMP-Caribbean Coral Reef, Seagrass and Mangrove Sites, ed. B. Kjerfve (Paris: UNESCO), 115-126.

Garzón-Ferreira, J., Cortés, J., Cróquer, A., Guzmán, H., Leão, Z., and RodríguezRamírez, A. (2000). "Status of coral reefs in southern tropical America: Brazil, Colombia, Costa Rica, Panamá and Venezuela," in Status of the Coral Reefs of the World: 2000, ed. C. Wilkinson (Townsville: AIMS), 331-348.

Garzón-Ferreira, J., Cortés, J., Cróquer, A., Guzmán, H., Leão, Z., and RodríguezRamírez, A. (2002). "Status of coral reefs in Southern Tropical America in
2000-2002: Brazil, Colombia, Costa Rica, Panamá and Venezuela,' in Status of Coral Reefs of the World: 2002, ed. C. Wilkinson (Townsville: AIMS), 343-360. Garzón-Ferreira, J., Cortés, J., Cróquer, A., Guzmán, H., Leão, Z., and Rodríguez-Ramírez, A. (2004). "Southern tropical America: coral reef status and consolidation as GCRMN node," in Status of the coral reefs of the world: 2004, Vol. 2, ed. C. Wilkinson (Townsville: AIMS), 509-522.

Gayle, P., Charpentier, B., Spence, O., and Levrel, A. (2010). The Jamaican CARICOMP Site: using a temporal data set to assist in managing coastal resources. Rev. Biol. Trop. 58(Suppl. 3), 63-69.

Gayle, P. M. H., and Woodley, J. D. (1998). "Discovery Bay, Jamaica," in CARICOMP-Caribbean Coral Reef, Seagrass and Mangrove Sites, ed. B. Kjerfve (Paris: UNESCO), 17-34.

Gerace, D. T., Ostrander, G. K., and Smith, G. W. (1998). “San Salvador, Bahamas,” in CARICOMP-Caribbean Coral Reef, Seagrass and Mangrove Sites, ed. B. Kjerfve (Paris: UNESCO), 229-246.

Geraldes, F. X. (1998). "Parque Nacional del Este, Dominican republic," in CARICOMP-Caribbean Coral Reef, Seagrass and Mangrove Sites, ed. B. Kjerfve (Paris: UNESCO), 213-222.

Giri, C., Ochieng, E., Tieszen, L., Zhu, Z., Singh, A., Loveland, T., et al. (2011). Status and distribution of mangrove forests of the world using earth observation satellite data. Glob. Ecol. Biogeogr. 20, 154-159. doi: 10.1016/j.jenvman.2014.01. 020

Grech, A., Chartrand-Miller, K., Erftemeijer, P., Fonseca, M., McKenzie, L., Rasheed, M., et al. (2012). A comparison of threats, vulnerabilities and management opportunities in global seagrass bioregions. Environ. Res. Lett. 7:024006. doi: 10.1088/1748-9326/7/2/024006

Guzman, H. M., Barnes, P. A. G., Lovelock, C. E., and Feller, I. C. (2005). A site description of the CARICOMP mangrove, seagrass and coral reef sites in Bocas del Toro, Panamá. Caribe J. Sci. 41, 430-440.

Harvell, D., Jordán-Dahlgren, E., Merkel, E., Rosenberg, E., Raymundo, L., Smih, G., et al. (2007). Coral diseases, Environmental drivers and the balance between corals and microbial associates. Oceanography 20, 58-81. doi: 10.5670/ oceanog.2007.91

Herrera-Silveira, J., and Ramírez-Ramírez, J. (1998). "Laguna de Celestún, Yucatán, México," in CARICOMP-Caribbean Coral Reef, Seagrass and Mangrove Sites, ed. B. Kjerfve (Paris: UNESCO), 43-56.

Hughes, T. P. (1994). Catastrophes, phase shifts, and large-scale degradation of a Caribbean coral reef. Science 265, 1547-1551. doi: 10.1126/science.265.5178. 1547

Jackson, J. B. C., Donovan, M. K., Cramer, K. L., and Lam, V. V. (eds). (2014). Status and Trends of Caribbean Coral Reefs: 1970-2012. Gland: IUCN, 304.

Juman, R. A. (2005a). Biomass, litterfall and decomposition rates for the fringed Rhizophora mangle forest lining the Bon Accord Lagoon, Tobago. Rev. Biol. Trop. 53(Suppl. 1), 207-217.

Juman, R. A. (2005b). The structure and productivity of the Thalassia testudinum community in Bon Accord Lagoon, Tobago. Rev. Biol. Trop. 53(Suppl. 1), 219-227.

Kjerfve, B. (ed.). (1998). CARICOMP - Caribbean Coral Reef, Seagrass and Mangrove Sites. Coastal Region and Small Island Papers 3. Paris: UNESCO, 347.

Koltes, K. H., and Opishinski, T. B. (2009). Patterns of water quality and movement in the vicinity of Carrie Bow Cay, Belize. Smithson. Contr. Mar. Sci. 38, 379-390.

Koltes, K. H., Tschirky, J. J., and Feller, I. C. (1998). “Carrie Bow Cay, Belize," in CARICOMP-Caribbean Coral Reef, Seagrass and Mangrove Sites, ed. B. Kjerfve (Paris: UNESCO), 79-94.

Laboy-Nieves, E. N., Klein, E., Conde, J. E., Losada, F., Cruz, J. J., and Bone, D. (2001). Mass mortality of tropical marine communities in Morrocoy, Venezuela. Bull. Mar. Sci. 68, 163-179.

Lang, J. C., Lasker, H. R., Gladfelter, E. H., Hallock, P., Jaap, W. C., Losada, F. J., et al. (1992). Spatial and temporal variability during periods of "recovery" after mass bleaching on Western Atlantic coral reefs. Am. Zool. 32, 696-706. doi: $10.1093 / \mathrm{icb} / 32.6 .696$

Laydoo, R. S., Bonair, K., and Alleng, G. (1998). "Buccoo reef and bon accord Lagoon, Tobago, Republic of Trinidad \& Tobago," in CARICOMP-Caribbean Coral Reef, Seagrass and Mangrove Sites, ed. B. Kjerfve (Paris: UNESCO), $171-176$. 
Linton, D., and Fisher, T. (2004). Caribbean Coastal Marine Productivity Program, 1993-2004. Kingston: CARICOMP, 91.

Linton, D. M., and Woodley, J. D. (1998). "The Data Management Centre and data summary," in CARICOMP-Caribbean Coral Reef, Seagrass and Mangrove Sites, ed. B. Kjerfve (Paris: UNESCO), 259-334.

López-Calderón, J. M., Guzmán, H. M., Jácome, G. E., and Barnes, P. A. G. (2013). Decadal increase in seagrass biomass and temperature at the CARICOMP site in Bocas del Toro, Panamá. Rev. Biol. Trop. 61, 1815-1826. doi: 10.15517/rbt. v61i4.12854

Loría-Naranjo, M., Samper-Villarreal, J., Sandoval-Siles, M., and Cortés, J. (2018). Intra and inter annual variation in a seagrass meadow on the Caribbean coast of Costa Rica: 2009-2015. Rev. Biol. Trop. 66, 1149-1161. doi: 10.15517/rbt.v66i3. 31035

Loya, J. (1978). "Plotless and transect methods," in Coral Reefs: Research Methods, ed. D. R. Stoddart, and R. E. Johannes (Paris: UNESCO), 197-217.

Maxwell, P., Eklof, J., van Katwijk, M. M., O’Brien, K., de la Torre-Castro, M., Boström, C., et al. (2017). The fundamental role of ecological feedback mechanisms in seagrass ecosystems-A review. Biol. Rev. 92, 1521-1538. doi: $10.1111 /$ brv.12294

McKenzie, L. J., Long, L., Coles, R. G., and Roder, C. A. (2000). Seagrass-Watch: community based monitoring of seagrass resources. Biol. Mar. Mediterr. 7, 393-396.

McRoy, C. P., and Helfferich, C. (eds). (1977). Seagrass Ecosystems-A Scientific Perspective. (New York, NY: Marcel Dekker Inc.), 314.

Murdoch, T. J. T., Glasspool, A. F., Outerbridge, M., Ward, J., Manuel, S., Gray, J., et al. (2007). Large-scale decline in offshore seagrass meadows in Bermuda. Mar. Ecol. Prog. Ser. 339, 123-130. doi: 10.3354/meps339123

Nagelkerken, I., Buchan, K., Smith, G. W., Bonair, K., Bush, P., Garzón-Ferreira, J., et al. (1997). "Widespread disease in Caribbean sea fans: I. Spreading and general characteristics," in Proceedings of the 8th International Coral Reef Symposium, Vol. 1, Panamá, 679-682.

Nielsen-Muñoz, V., and Cortés, J. (2008). Abundancia, biomasa y floración de Thalassia testudinum (Hydrocharitaceae) en el Caribe de Costa Rica. Rev. Biol. Trop. 56(Suppl. 4), 175-189.

Ogden, J. C. (1987). Cooperative coastal ecology at marine laboratories. Oceanus 30, 9-14.

Ogden, J. C., and Gladfelter, E. H. (eds). (1983). "Coral reefs, seagrass beds and mangroves. Their interaction in the coastal zones of the Caribbean," in Report of a Workshop, Held at West Indies Laboratory, St. Croix, U. S. Virgin Islands May, 1982, (Paris: UNESCO), 23-133.

Ogden, J. C., and Gladfelter, E. H. (1986). Caribbean coastal marine productivity: results of a planning workshop. UNESCO Rep. Mar. Sci. 41:59.

Ogden, J. C., Nagelkerken, I., and McIvor, C. (2014). "Connectivity in the tropical coastal seascape: implications for marine spatial planning and resources management," in Interrelationships Between Corals and Fisheries, ed. S. Bortone (Boca Raton, FL: CRC Press), 253-273.

Parker, C., and Oxenford, H. A. (1998). "Barbados," in CARICOMP-Caribbean Coral Reef, Seagrass and Mangrove Sites, ed. B. Kjerfve (Paris: UNESCO), 177-186.

Paynter, C. K., Cortés, J., and Engels, M. (2001). Biomass, productivity and density of the seagrass Thalassia testudinum at three sites in Cahuita National Park, Costa Rica. Rev. Biol. Trop. 49(Suppl. 2), 265-272.

Pérez, D., Guevara, M., and Bone, D. (2006). Temporal variation of biomass and productivity of Thalassia testudinum (Hydrocharitaceae) in Venezuela, Southern Caribbean. Rev. Biol. Trop. 54, 329-339. doi: 10.15517/rbt.v54i2. 13873

Polidoro, B. A., Carpenter, K. E., Collins, L., Duke, N. C., Ellison, A. M., Ellison, J. C., et al. (2010). The loss of species: mangrove extinction risk and geographic áreas of global concern. PLoS One 5:e10095. doi: 10.1371/journal.pone. 0010095

Pors, L. P. J. J., and Nagelkerken, I. A. (1998). "Curaçao, Netherlands Antilles," in CARICOMP-Caribbean Coral Reef, Seagrass and Mangrove Sites, ed. B. Kjerfve (Paris: UNESCO), 127-140.

Potts, A. C., Sandy, K., Clarke, M., and Bobb, N. (2004). "The coral reefs of Tobago: status and management," in Proceedings of the 55th Gulf and Carbbean Fisheries Institute, Chetumal, 765-776.

Richardson, L. L. (1998). Coral diseases: what is really known? Trends Ecol. Evol. $13,438-443$
Rodríguez-Martínez, R. E., Ruíz-Rentería, F., Van Tussenbroek, B. I., BarbaSantos, G., Escalante-Mancera, E., Jordán-Garza, G., et al. (2010). Environmental state and tendencies of the Puerto Morelos CARICOMP site, México. Rev. Biol. Trop. 58(Suppl. 3), 23-43.

Rodríguez-Ramírez, A., Bastidas, C., Cortés, J., Guzmán, H., Leão, Z., GarzónFerreira, J., et al. (2008a). "Status of coral reefs and associated ecosystems in Southern Tropical America: Brazil, Colombia, Costa Rica, Panamá and Venezuela," in Status of Coral Reefs of the World: 2008, ed. C. Wilkinson (Townsville: Global Coral Reef Monitoring Network and Reef and Rainforest Research Center), 281-294.

Rodríguez-Ramírez, A., Bastidas, C., Rodríguez, S., Leão, Z., Kikuchi, R., Oliveira, M., et al. (2008b). "The effects of coral bleaching in Southern tropical America: Brazil, Colombia, and Venezuela," in Status of Coral Reefs of the World: 2008, ed. C. Wilkinson (Townsville: Global Coral Reef Monitoring Network, and Reef and Rainforest Research Center), 105-114.

Rodríguez-Ramírez, A., Garzón-Ferreira, J., Batista-Morales, A., Gil, D. L., GómezLópez, D. I., Gómez-Campo, K., et al. (2010a). Temporal patterns in coral reef, seagrass and mangrove communities from Chengue bay CARICOMP site (Colombia): 1993-2008. Rev. Biol. Trop. 58(Suppl. 3), 45-62.

Rodríguez-Ramírez, A., Reyes-Nivia, M. C., Zea, S., Navas-Camacho, R., GarzónFerreira, J., Bejarano, S., et al. (2010b). Recent dynamics and conditions of coral reefs in the Colombian Caribbean. Rev. Biol. Trop. 58(Suppl. 1), 107-131.

Ruíz-Rentería, F., van Tussenbroek, B. I., and Jordán-Dahlgren, E. (1998). "Puerto Morelos, Quintana Roo, México," in CARICOMP-Caribbean Coral Reef, Seagrass and Mangrove Sites, ed. B. Kjerfve (Paris: UNESCO), 57-66.

Ryan, J., and Zapata, Y. (2003). "Nicaragua's coral reefs: status, health and management strategies," in Latin American Coral Reefs, ed. J. Cortés (Amsterdam Elsevier), 203-222. doi: 10.1016/B978-044451388-5/50010-2

Ryan, J. D., Miller, L. J., Zapata, Y., Downs, O., and Chan, R. (1998). "Great Corn Island, Nicaragua," in CARICOMP-Caribbean Coral Reef, Seagrass and Mangrove Sites, ed. B. Kjerfve (Paris: UNESCO), 95-108.

Short, F. T., Koch, E. W., Creed, J. C., Magalhães, K. M., Fernandez, E., and Gaeckle J. L. (2006). SeagrassNet monitoring across the Americas: case studies of seagrass decline. Mar. Ecol. 27, 277-289. doi: 10.1111/j.1439-0485.2006.00095.x

Sierra-Rozo, O., Gavio, B., and Mancera-Pineda, J. E. (2012). Estructura de las praderas de Thalassia testudinum en la Isla de Providencia, Caribe colombiano, después del paso del huracán Beta. Caldasia 34, 155-164.

Smetacek, V., and Zingone, A. (2013). Green and golden seaweed tides on the rise. Nature 504, 84-88. doi: 10.1038/nature 12860

Smith, S. R. (1998). "Bermuda," in CARICOMP-Caribbean Coral Reef, Seagrass and Mangrove Sites, ed. B. Kjerfve (Paris: UNESCO), 247-258.

Smith, S. R., Ogden, J. C., Alcolado, P. M., Bone, D., Bush, P., Cortés, J., et al. (1994). "Status and recent history of coral reefs at the CARICOMP network of Caribbean marine laboratories" in Proceedings of the Colloquium on Global Aspects of Coral Reefs: Health, Hazards and History, 1993, Compiler, ed. R. N. Ginsburg (Miami, FL: Rosenstiel School of Marine and Atmospheric Science), 73-79.

Spalding, M., Kainuma, M., and Collins, L. (2010). World Atlas of Mangroves. ITTO, ISME, FAO, UNEP-WCMC, UNESCO-MAB and UNUINWEH. London: Earthscan Publications Ltd. doi: 10.4324/97818497 76608

Valiela, I., Bowen, J. L., York, J. K., and York, O. K. (2001). Mangrove forests: one of the world's threatened major tropical environment. Bioscience 51, 807-815. doi: 10.1641/0006-3568(2001)051[0807:MFOOTW]2.0.CO;2

Van Dijk, K.-J., Bricker, E., van Tussenbroek, B. I., and Waycott, M. (2018). Range wide population genetic structure of the Caribbean marine angiosperm Thalassia testudinum. Ecol. Evol. 8, 9478-9490. doi: 10.1002/ece3.4443

Van Tussenbroek, B. I. (2011). Dynamics of seagrasses and associated algae in coral reef lagoons. Hidrobiológica 21, 293-310.

Van Tussenbroek, B. I., Cortés, J., Collin, R., Fonseca, A. C., Gayle, P. M. H., Guzman, H., et al. (2014). Caribbean-wide, long-term study of seagrass beds reveals local variations, shifts in community structure and occasional collapse. PLoS One 9:e90600. doi: 10.1371/journal.pone.0090600

Van Tussenbroek, B. I., Hernández Arana, H. A., Rodríguez-Martínez, R. E., Espinoza-Avalos, J., Canizales-Floresa, H. M., González-Godoy, C. E., et al. (2017). Severe impacts of brown tides caused by Sargassum spp. On nearshore Caribbean seagrass communities. Mar. Pollut. Bull. 122, 272-281. doi: 10.1016/j.marpolbul.2017.06.057 
Varela, R. J., Llano, M., Capelo, J. C., and Velázquez, Y. (1998). “Punta de Mangle, Isla de Margarita, Venezuela," in CARICOMP-Caribbean Coral Reef, Seagrass and Mangrove Sites, ed. B. Kjerfve (Paris: UNESCO), 161-170.

Vermeer, L. A. (2000). Changes in Growth and Abundance of Seagrasses in Barbados, West Indies. Ph.D. Dissertation, Dalhousie University, Halifax.

Webber, M., Calumpong, H., Ferreira, B., Granek, E., Green, S., Ruwa, R., et al. (2016). Mangroves. Chapter 48," in: United Nations, Treaty Series 996. Available at: http://www.un.org/depts/los/global_reporting/WOA_RPROC/Chapter -48.pdf

Williams, S. L. (1990). Experimental studies of Caribbean seagrass bed development. Ecol. Monogr. 60, 449-469. doi: 10.2307/1943015

Wilson, R. (2017). Impacts of climate change on mangrove ecosystems in the coastal and marine environments of the Caribbean small island developing states (SIDS). Sci. Rev. 2017, 61-82.

Woodley, J. D. (1998). "Establishment of coastal ecosystem monitoring programs: lessons learned by CARICOMP", in Proceedings of the International Tropical
Marine Ecosystems Management Symposium (ITMEMS), eds I. Dight, R. Kenchington, and J. Baldwin (Townsville: Great Barrier Reef Marine Park Authority), 327-328.

Zieman, J. C. (1982). The Ecology of Seagrasses of South Florida: A Community Profile. Washington, DC: U.S. Fish and Wildlife Services, 158.

Conflict of Interest Statement: The authors declare that the research was conducted in the absence of any commercial or financial relationships that could be construed as a potential conflict of interest.

Copyright (๑) 2019 Cortés, Oxenford, van Tussenbroek, Jordán-Dahlgren, Cróquer, Bastidas and Ogden. This is an open-access article distributed under the terms of the Creative Commons Attribution License (CC BY). The use, distribution or reproduction in other forums is permitted, provided the original author(s) and the copyright owner(s) are credited and that the original publication in this journal is cited, in accordance with accepted academic practice. No use, distribution or reproduction is permitted which does not comply with these terms. 